Keywords:

High Level Waste

Characterization

Supernate

\title{
HLW SUPERNATE
}

RADIONUCLIDE CHARACTERIZATION (U)

Retention: Permanent

Revised By

R. F. O'Bryant and W. R. Weiss

Issued: March 2003

\section{APPROVALS}

R. F. Q'Brant, EBU Engineering, Co-Author

$$
\text { upuies }
$$

W. R. Weiss, DFM for CBU Engineering, Co-Author 2852 he

L. E. Rykken, DFM for CBU Engineering, Technical Reviewer

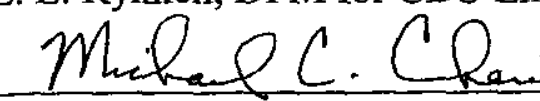

M. C. Chandler, CBU Engineering

\section{Classification: $\mathbf{U}$}

Does not Contain UCNI

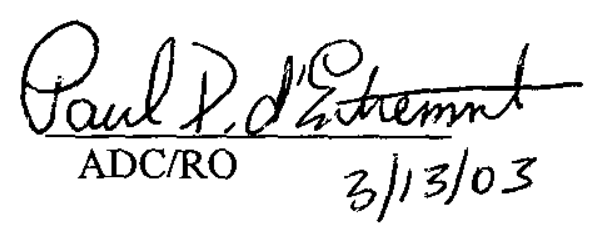

Date: $3 / 11 / 03$

Date: $3 / 1,03$

Date: $3 / 1 / 03$

Date: $3 / 12 / 03$ 


\section{TABLE OF CONTENTS}

Revision Description................................................................................

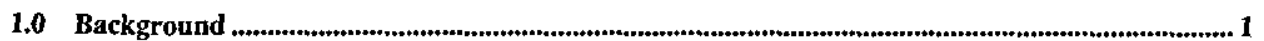

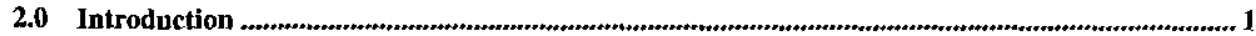

3.0 Development of a Radionuclide Distribution for Supernate-Contaminated Waste ....................... 2

3.1 Determining the Initial List of Radionuclides

3.2 Excluding Radionuclides from Consideration

3.3 Development of the Supernate Distribution

3.4 Other WAC Criteria

3.4.1 Comparison to Package Guidelines

3.4.2 Sum-of-Fractions Calculation

3.4.3 Nuclear Criticality Safety Criteria

3.5 Documentation of the Supernate Distribution

4.0 Periodic Validation 
WSRC-TR-94-00290

Revision 4

Page ii

\title{
ATTACHMENTS
}

\author{
Attachment 1 \\ F- and H-Area Tank Farms WCS Tank Data \\ Attachment 2 \\ F- and $\mathrm{H}$-Area Tank Farms WCS Supernate Inventory \\ Attachment 3 \\ Calculation of Supernate Concentrations from WCS Supernate Inventory and Tank Data \\ Attachment 4 \\ Attachment 5 \\ Conversion of March 1999 Supernate Ci/gal Values for Decay to March 2003 \\ Attachment 6 \\ F- and H-Area Tank Farms Historic Supernate Data \\ Attachment 7 \\ Projected Americium/Curium Transfer from F-Canyon to H-Area Tank 51 \\ Attachment 8 \\ F-Area Tank Farm Sludge Inventory from WCS \\ Calculation of $95 \mathrm{Ci} \%$ Supernate $/ 5 \mathrm{Ci} \%$ Sludge Scaling Factors \\ Attachment 9 \\ F- and H-Area High Level Supernate Waste Stream Exclusion Criteria \\ Attachment 10 \\ F- and H-Area High Level Supernate Waste Stream Activity Distribution \\ Attachment 11 \\ Attachment 12 \\ Comparison of F- And H-Area Waste Against WAC 3.17, Revision 7, Requirements \\ Comparison of Burial Ground Parameters for $100 \%$ Supernate and \\ 95/5 Ci\% Supernate/Sludge Mixture \\ Attachment 13 \\ Waste Characterization Form for FHW-00001
}

Table 3.1

Table 3.2

Table 3.3

Table 3.4

Table 3.5

Table 3.6

Table 3.7

LIST OF TABLES

Table 3.8

Table 4.1

Radionuclides Important to Characterization of the Supernate-Contaminated Waste

Radionuclides Excluded from Consideration, Supernate

Radionuclide Activity Distribution and Scaling Factors for F- and H-Area Tank Farms Supernate

Comparison of Supernate-Contaminated Waste to LAWV Limits

Comparison of Maximum Amount of Supernate Present to Meet LAWV limits vs. TRU Criteria

Sum-of-Fractions for Supernate-Contaminated Waste

Comparison of Maximum Amount of Supernate Present to Meet LAWV Sum-of Fraction

Limits vs. TRU Criteria

Calculation of FGE Equivalent for Supernate-Contaminated Waste

Validated Radionuclide Distribution and Scaling Factors for F- and H-Area Tank Farms Supernate 


\section{Revision Description}

This revision to this document includes the following substantive changes to the Revision 3 document:

- Updates and revalidates the consolidation of F- and H-Area high level supernate waste into a single supernate waste stream that includes an estimated $5 \mathrm{Ci} \%(\sim 1 \mathrm{wt} \%)$ sludge solids The technical basis for this is WSRC-TR-97-0055, Revision 2, "HLW Sludge Beta Screening Tool" (Reference 4), which concludes that a waste package that "passes" measurement by the beta screening tool, i.e., displays a Cs$137 / \mathrm{Sr}-90$ ratio $>17$, may have up to $5 \mathrm{Ci} \%$ sludge solids. Therefore, this revised distribution represents a conservative distribution that allows for a small amount of incidental sludge contamination. 
Characterization of High Level Waste (HLW) Division supernate waste by the Concentration Storage and Transfer (CST) Department [now the Closure Business Unit (CBU)] is outlined in WSRC-TR-94-0290, Revision 3, HLW Supernate Radionuclide Characterization (Reference 1), which provided characterization and validation for the radionuclide content and distribution of supernate-contaminated waste generated during operations, maintenance, and construction activities conducted in the F- and H-Area Tank Farms. Salt managed in the F- and H-Area Tank Farms has the same radionuclide distribution as supernate and, accordingly, the supernate characterization and validation also covered salt-contaminated waste.

The characterization of supernate waste discussed in Reference 1 was based primarily on process knowledge. Validation was based on the results of analyses of samples collected and analyzed within two years prior to the publication of the document. The document did not differentiate between waste generated in the F- and H-Areas, but provided a single characterization for the entire supernate waste stream generated in these areas.

The Waste Characterization System (WCS) was established in 1996 to consolidate waste characterization information. Inventories and compositions of major radionuclide and chemical constituents are based on tank fill histories. Minor constituent inventories are based on compositions developed during DWPF design. Fill histories for each tank are also contained in the WCS (Reference 2). Subsequent analytical data is incorporated into this database as deemed appropriate.

The current document provides a recharacterization and revalidation for supernate- and salt-contaminated waste generated from the $\mathrm{F}$ - and $\mathrm{H}$-Area Tank Farms, based on current process knowledge and available analytical data. The scaling factors developed in this document supercede those presented in Reference 1, and any other previously-developed radionuclide characterizations for F- and H-Area Tank Farm supernateand salt-contaminated waste.

\section{Introduction}

This document will develop a radionuclide distribution for supernate-contaminated waste stored in the $\mathrm{F}$ and H-Area Tank Farms in accordance with the methodology outlined in WSRC 1S SRS Waste Acceptance Criteria Manual, Procedure 2.02 Low Level, Hazardous, TRU, Mixed, and PCB Waste Characterization Requirements, Revision 7 (Reference 3). This distribution is based on the assumptions that (1) supernatecontaminated waste from all F- and H-Area High Level Waste Tanks could be co-mingled, and the actual contamination present on waste in a series of containers from these tanks will be representative of the mean radionuclide distribution, and (2) high level supemate waste from F- and H-Area tanks contains up to $5 \mathrm{Ci} \%$ sludge solids (Reference 4).

The original characterization of F- and H-Area high level supernate waste was based primarily on process knowledge and fill histories; a single, comprehensive characterization for supernate was developed from this information (Reference 1).

Most of the waste contaminated with supernate from the F- and H-Area Tank Farms will be categorized as Low Level Waste (LLW) and disposed of in the E-area Vaults (EAV). The waste does, however, have the potential to be categorized as TRU and/or mixed waste. Quantification of hazardous constituents and determination of whether the waste is classified as mixed is dependent on the amount of supernate present on the waste matrix and the nature of the waste matrix, and will be performed on a case-by-case basis. Quantification of radionuclides present in each waste package will be performed as described in Section 5.0 .

The radionuclide distribution developed for LLW contaminated with supernate from the F- and H-Area Tank Farms can also be applied to waste classified as transuranic. [Neither WSRC 1S SRS Waste Acceptance Criteria Manual, Procedure 3.06, E-Area TRU Pads Transuranic Waste Acceptance Criteria, 
Revision 5, nor Appendix A:34, TRU Waste Container Characterization Form (OSR 29-90) Instruction specifies a methodology for determination of the isotopic distribution in TRU Waste; simply that the methodology be documented.]

WSRC 1S SRS Waste Acceptance Criteria Manual, Procedure 2.02, Revision 7 (Reference 3), allows generators to use scaling factors derived from process knowledge and/or sampling and analysis data to characterize the radionuclide content of the waste. Since the availabie record of supernate sample data is limited (primarily due to the logistical difficulties and ALARA considerations associated with sampling the high level waste tanks), this characterization is based primarily on process knowledge of tank fill histories and compositions developed during limited supernate sampling as reflected in the WCS (Reference 2). Periodic validation of the distribution developed in this document will be performed as discussed in Section 6.

\section{Development of a Radionuclide Distribution for Supernate-Contaminated Waste}

The development of the radionuclide distribution in this section is performed per guidance outlined in WSRC 1S SRS Waste Acceptance Criteria Manual, Procedure 2.02, Revision 7 (Reference 3). The distribution was developed assuming a potential mixture of $95 \mathrm{Ci} \%$ supernate to $5 \mathrm{Ci} \%$ sludge based on current WCS data. The technical basis for this is WSRC-TR-97-0055, Revision 2, "HLW Sludge Beta Screening Tool" (Reference 4), which concludes that a waste package that "passes" the beta screening tool, i.e., displays a Cs-137/Sr-90 ratio $>17$, may have up to $5 \mathrm{Ci} \%(\sim \mathrm{I} \mathrm{wt} \%)$ sludge solids. Therefore, the radionuclide distribution resulting from this new characterization represents a conservative distribution that allows for a small amount of incidental sludge contamination. Since dose-to-curie is the characterization method of choice for F- and H-Area Tank Farm waste, this new characterization is also conservative for waste that has less than $5 \mathrm{Ci} \%$ sludge solids. [Note: This is illustrated in Attachment 12 where a B-25 with $5000 \mathrm{lb}$ maximum weight $100 \mathrm{Ci} \%$ supernate-contaminated waste (Case 1) is compared to an identical B-25 with maximum weight $95 \mathrm{Ci} \%$ supernate $/ 5 \mathrm{Ci} \%$ sludge-contaminated waste (Case 2 ) each with a dose rate of $1 \mathrm{mrem} / \mathrm{hr}$ at $5 \mathrm{ft}$. The E-Area Vault PA sum-of-fractions is nearly identical while the $\mathrm{nCi} / \mathrm{gm}$ of TRU components is significantly higher in Case 2.]

\subsection{Determining the Initial List of Radionuclides}

WSRC IS SRS Waste Acceptance Criteria Manual, Procedure 2.02, Revision 7 (Reference 3), stipulates that the characterization of each package of waste having a total activity greater than 2 nanocuries/gram must consider the potential presence of any radionuclide that meets any one of three criteria:

1. The radionuclide is identified in WSRC 1S SRS Waste Acceptance Criteria Manual, Procedure 3.17, Low Level Waste Acceptance Criteria, Revision 7 (Reference 5), as being a Performance Assessment (PA) or Safety Authorization (SA) Basis radionuclide for a specific Treatment, Storage or Disposal (TSD) facility. For purposes of this distribution, we will use those PA and SA radionuclides for the EAV.

2. The radionuclide could be present in the waste with a relative activity greater than $1.0 \%$ of the total waste stream activity at the time of the characterization.

3. The radionuclide is a detectable transuranic or a fissile radionuclide.

The above criteria are hereafter referred to as "inclusion criteria."

Based on the three inclusion criteria and available process knowledge, the following list of 31 radionuclides (Table 3.1) will be considered when developing the radionuclide distribution of waste packages contaminated with supernate from the F- and H-Area Tank Farms. 


\begin{tabular}{|c|c|c|c|c|}
\hline \multirow[b]{2}{*}{ Radionuclide } & \multicolumn{2}{|c|}{3,1} & \multicolumn{2}{|l|}{ Inclusion Criteria } \\
\hline & $\begin{array}{l}\text { PA } \\
\text { Limiting }\end{array}$ & $\begin{array}{c}\mathbf{S A} \\
\text { Limiting } \\
\end{array}$ & $\begin{array}{l}\text { Potentially Present } \\
\text { At }>1 \% \text { Total Activity }\end{array}$ & $\begin{array}{l}\text { Detectable Fissile or } \\
\text { TRU Radionuclíde }\end{array}$ \\
\hline $\mathrm{H}-3$ & & SA & & \\
\hline C. 14 & $\mathrm{PA}$ & & & \\
\hline $\mathrm{Ni}-59$ & & & $\mathrm{X}$ & \\
\hline $\mathrm{Co}-60$ & & & $\mathrm{X}$ & \\
\hline $\mathrm{Ni}-63$ & & & $X$ & \\
\hline Sr-90 & & & $\mathrm{X}$ & \\
\hline $\mathrm{Y}-90$ & & & Daughter of Sr-90 & \\
\hline Tc-99 & PA & & & \\
\hline $\mathrm{I}-129$ & PA & & & \\
\hline Cs-137 & & & $\mathrm{X}$ & \\
\hline $\mathrm{Ba}-137 \mathrm{~m}$ & & & Daughter of Cs-137 & \\
\hline $\mathrm{Pm}-147$ & & & $\mathrm{X}$ & \\
\hline $\mathrm{Eu}-154$ & & & $X$ & \\
\hline $\mathrm{U}-233$ & & & $\mathrm{X}$ & Detectable Fissile \\
\hline U-234 & PA & & & \\
\hline $\mathrm{U}-235$ & & & $\mathrm{X}$ & Detectable Fissile \\
\hline U.238 & PA & & & \\
\hline $\mathrm{Np}-237$ & & & $\mathrm{X}$ & Detectable TRU \\
\hline $\mathrm{Np}-239$ & & & $\mathrm{X}$ & \\
\hline Pu-238 & & & $\mathrm{X}$ & Detectable TRU \\
\hline Pu-239 & & & $X$ & Detectable Fissile, TRU \\
\hline $\mathrm{Pu}-240$ & & & $\mathrm{X}$ & Detectable TRU \\
\hline $\mathrm{Pu}-241$ & & & $X$ & Detectable Fissile \\
\hline $\mathrm{Pu}-242$ & & & $\mathrm{X}$ & Detectable TRU \\
\hline $\mathrm{Am}-241$ & & & $X$ & Detectable TRU \\
\hline $\mathrm{Am}-242 \mathrm{~m}$ & & & $X$ & Detectable Fissile, TRU \\
\hline $\mathrm{Am}-243$ & & & $\mathrm{X}$ & Detectable TRU \\
\hline $\mathrm{Cm}-244$ & & & $\mathrm{X}$ & \\
\hline $\mathrm{Cm}-245$ & & & $\mathrm{X}$ & Detectable Fissile, TRU \\
\hline $\mathrm{Cm}-246$ & & & $X$ & Detectable TRU \\
\hline $\mathrm{Cm}-247$ & & & $\mathrm{X}$ & Detectable Fissile, TRU \\
\hline
\end{tabular}

The supernate radionuclide distribution determined in the present characterization is based on the previous supernate characterization (Reference 1) and data presently contained in the WCS for F- and H-Area HLW tanks (Attachments 1, 2, and 3). The WCS was established in 1996 to consolidate waste characterization information. Inventories and compositions of major waste tank constituents are based on tank fill histories. Minor constituent inventories are based on compositions developed during design of the Defense Waste Processing Facility. Subsequent analytical data are incorporated into the WCS as deemed appropriate.

For the current characterization, if supernate data were not available in the WCS for a radionuclide highlighted as important in the previous characterization (Reference 1), the previous characterization distribution values were used, after correction for decay since 1999 (Attachments 4 and 5).

Scaling factors and Ci\% distributions for radionuclides known to be present in sludge solids in the F- and $\mathrm{H}$-Area Tank Farms were calculated from decay-corrected radionuclide inventories and tank volume data in the WCS, as well as projections for a significant transfer of a solution of americium and curium from F- 
Canyon to H-Area Tank 51 that has recently occurred but not yet been incorporated into the WCS (Reference 6; Attachments 1,6, and 7).

Waste stream averages for radionuclide distribution data and resultant scaling factors are conservatively calculated to include only those tanks that contained the particular radionuclide, i.e., zero concentrations are not included in the averages. All tanks that were reported to have both a sludge layer and a supernatant layer were used to determine average radionclide values. This is consistent with the analysis that was done in Reference 4. To be consistent with the waste stream consolidation criteria of Reference 3, PA isotope levels in the approved $\mathrm{H}$ - and F-Area Tank Farm waste streams (References 6 and 7) were checked to ensure that the individual values were within a factor of 10 of the average for all included tanks. This was true for all PA isotopes except I-129; for this isotope, only the tanks included in the approved waste streams were used to obtain an average that met the Reference 3 WAC 2.02 criteria.

After development of the two consolidated waste streams [supernate (Attachment 5) and sludge (Attachment 7)], these two were combined in Attachment 8 to represent the new combined $95 \mathrm{Ci} \%$ supernate $-5 \mathrm{Ci} \%$ sludge waste stream, FHW-00001.

\subsection{Excluding Radionuclides from Consideration}

Under WAC 2.02, Revision 7, radionuclides that meet one of the inclusion criteria outlined in section 3.1 may be excluded from further consideration for a waste stream if one or more of the following conditions exist:

1. There is no reason to expect the radionuclide to be present in the waste stream.

2. For non-SA or -PA radionuclides, or non-detectable fissile or TRU radionuclides, the individual activity contribution is less than $1 \%$ of the total radionuclide activity.

The above criteria are hereafter referred to as "exclusion criteria;" exclusion results are presented in Table 3.2.

(Note: WSRC 1S SRS Waste Acceptance Criteria Manual, Procedure WAC 2.02, Revision 7, also allows for exclusion from the waste stream distribution of radionuclides whose activities are below specific analytical laboratory Maximum Allowable Lower Limits of Detection [MALLDs]. For conservatism, this exclusion criterion will not be used for this primarily process-knowledge-based characterization of supernate waste.

Of the 31 radionuclides listed in Table 3.1, no radionuclide is excluded because it is not expected to be present; based on process knowledge and limited analytical data all the listed radionuclides could be present in supernate waste. Of the radionuclides included because they were expected to be present at more than $1 \%$ of total activity, 7 are determined to be present at less than $1 \%$ of the total activity in the waste stream. Two of these radionuclides, however, are retained in the distribution since they are near $1 \%$ of total activity. This determination is presented in Attachment 9. 


\begin{tabular}{|c|c|c|}
\hline \multicolumn{3}{|c|}{$\begin{array}{l}\text { Table 3.2. Radionuclides Excluded from Consideration, } \\
\text { Supernate }\end{array}$} \\
\hline \multirow{2}{*}{ Radionuclide } & \multicolumn{2}{|c|}{ Exclusion Criteria } \\
\hline & Not Expected & Present at $<1 \%$ \\
\hline H-3 & & $\mathrm{X}(\mathrm{b})$ \\
\hline \multicolumn{3}{|l|}{$\mathrm{C}-14$} \\
\hline $\mathrm{Ni}-59$ & & $X$ \\
\hline \multicolumn{3}{|l|}{$\mathrm{Co}-60$} \\
\hline $\mathrm{Ni}-63$ & & $\mathrm{X}$ \\
\hline \multicolumn{3}{|l|}{$\mathrm{Sr}-90$} \\
\hline \multicolumn{3}{|l|}{$\frac{Y-90}{T c-99}$} \\
\hline \multirow{2}{*}{\multicolumn{3}{|c|}{ Tc-99 }} \\
\hline & & \\
\hline \multicolumn{3}{|l|}{$\mathrm{Cs}+137$} \\
\hline \multicolumn{3}{|l|}{$B a-137 m$} \\
\hline Pm-147 & & $X(b)$ \\
\hline Eu-154 & & $\mathrm{X}$ \\
\hline \multicolumn{3}{|l|}{$\mathrm{U}-233$} \\
\hline \multicolumn{3}{|l|}{ U-234 } \\
\hline \multicolumn{3}{|l|}{$\mathrm{U}-235$} \\
\hline \multicolumn{3}{|l|}{$\mathrm{U}-238$} \\
\hline \multicolumn{3}{|l|}{$\mathrm{Np}-237$} \\
\hline Np-239 & & $X$ \\
\hline \multirow{2}{*}{\multicolumn{3}{|c|}{$\frac{\text { Pu-238 }}{\mathrm{Pu}-239}$}} \\
\hline \multirow{2}{*}{\multicolumn{3}{|c|}{$\frac{\mathrm{Pu}-239}{\mathrm{Pu}-240}$}} \\
\hline & & \\
\hline \multicolumn{3}{|l|}{$\mathrm{Pu}-241$} \\
\hline \multicolumn{3}{|l|}{ Pu-242 } \\
\hline \multicolumn{3}{|l|}{$\mathrm{Am}-241$} \\
\hline \multirow{2}{*}{\multicolumn{3}{|c|}{$\frac{A m-242 m}{A m-243}$}} \\
\hline & & \\
\hline $\mathrm{Cm}-244$ & & $X$ \\
\hline \multicolumn{3}{|l|}{$\mathrm{Cm}-245$} \\
\hline $\mathrm{Cm}-246$ & & \\
\hline $\mathrm{Cm}-247$ & & \\
\hline
\end{tabular}

(a) For those radionuclides included only because they were expected to be present at $>1 \%$

(b) Retained in distribution since they are close to $1 \%$ total activity NOTE: Bold $=$ PA/SA radionuclides 


\section{Development of the Supernate Distribution}

Thirty-one radionuclides were determined to be important for characterization of the supernate in F-and $\mathrm{H}$ Tank Farms to be quantified (Table 3.2). Current tank contents were used to update the scaling factors to create an isotopic distribution for the waste stream, assuming a potential $95 \mathrm{Ci} \%$ supernate $5 \mathrm{Ci} \%$ sludge mixture, as discussed in Section 3.2.

The radionuclides, their mean activity distribution, and mean scaling factors (to Cs-137) in the F- and $\mathrm{H}$ Area Tank Farm consolidated supernate waste stream are determined in Attachment 10 and Table 3.3.

\begin{tabular}{|c|c|c|c|}
\hline Radionuclide & $\begin{array}{l}\text { LAWV } \\
\text { Limiting } \\
\text { Category }\end{array}$ & $\begin{array}{c}\text { Activity Distribution } \\
\text { Normalized }(\%)\end{array}$ & $\begin{array}{l}\text { Scaling Factors } \\
\text { (Ci/Ci Cs-137) }\end{array}$ \\
\hline H-3 & SA & $1.59 \mathrm{E}-01$ & $3.28 \mathrm{E}-03$ \\
\hline C-14 & $\overline{P A}$ & $9.44 \mathrm{E}-05$ & $1.96 \mathrm{E}-06$ \\
\hline Co-60 & & $1.01 \mathrm{E}+00$ & $2.08 \mathrm{E}-02$ \\
\hline Sr-90 & & $2.29 \mathrm{E}+00$ & $4.74 \mathrm{E}-02$ \\
\hline$Y-90$ & & $2.29 \mathrm{E}+00$ & $4.74 \mathrm{E}-02$ \\
\hline Tc-99 & PA & $9.60 \mathrm{E}-03$ & $1.99 \mathrm{E}-04$ \\
\hline I-129 & PA & $9.94 \mathrm{E}-06$ & $2.06 \mathrm{E}-07$ \\
\hline Cs-137 & & $4.83 \mathrm{E}+01$ & $1.00 \mathrm{E}+00$ \\
\hline $\mathrm{Ba}-137 \mathrm{~m}$ & & $4.57 \mathrm{E}+01$ & $9.46 \mathrm{E}-01$ \\
\hline $\mathrm{Pm}-147$ & & $1.04 \mathrm{E}-01$ & $2.15 \mathrm{E}-03$ \\
\hline $\mathrm{U}-233$ & Fissile & $4.98 \mathrm{E}-06$ & $1.03 \mathrm{E}-07$ \\
\hline $\mathrm{U}-234$ & $\mathbf{P A}$ & $4.71 \mathrm{E}-06$ & $9.76 \mathrm{E}-08$ \\
\hline$U-235$ & Fissile & $1.42 \mathrm{E}-06$ & $2.94 \mathrm{E}-08$ \\
\hline U-238 & $\mathrm{PA}$ & $2.04 \mathrm{E}-06$ & $4.22 \mathrm{E}-08$ \\
\hline Np-237 & $\overline{T R U}$ & $2.31 E-06$ & $4.78 \mathrm{E}-08$ \\
\hline $\mathrm{Pu}-238$ & TRU & $6.24 \mathrm{E}-02$ & $1,29 \mathrm{E}-03$ \\
\hline Pu-239 & Fissile, TRU & $1.30 \mathrm{E}-03$ & $2.70 \mathrm{E}-05$ \\
\hline $\mathrm{Pu}-240$ & TRU & $2.70 \mathrm{E}-02$ & $5.58 \mathrm{E}-04$ \\
\hline $\mathrm{Pu}-241$ & Fissile & $3.47 \mathrm{E}-02$ & $7.18 \mathrm{E}-04$ \\
\hline $\mathrm{Pu}-242$ & TRU & $6.41 \mathrm{E}-04$ & $1.33 \mathrm{E}-05$ \\
\hline $\mathrm{Am}-241$ & TRU & $2.39 \mathrm{E}-02$ & $4.94 \mathrm{E}-04$ \\
\hline$A m-242 m$ & Fissile, TRU & $7.39 \mathrm{E}-04$ & $1.53 \mathrm{E}-05$ \\
\hline $\mathrm{Am}-243$ & TRU & $1.82 \mathrm{E}-03$ & $3.76 \mathrm{E}-05$ \\
\hline $\mathrm{Cm}-245$ & Fissile, TRU & $7.49 \mathrm{E}-06$ & $1.55 \mathrm{E}-07$ \\
\hline $\mathrm{Cm}-246$ & TRU & $2.49 \mathrm{E}-05$ & $5.15 \mathrm{E}-07$ \\
\hline $\mathrm{Cm}-247$ & Fissile, TRU & $1.21 \mathrm{E}-10$ & $2.51 \mathrm{E}-12$ \\
\hline Total Radionuclides & & $1.00 \mathrm{E}+02$ & $2.07 \mathrm{E}+00$ \\
\hline Total TRU & & & $2.44 \mathrm{E}-03$ \\
\hline
\end{tabular}




\subsubsection{Comparison to Package Guidelines}

Most supernate-contaminated waste will be disposed of in the E-Area Vaults. Administrative Waste Package Radiological Concentration Guidelines apply to waste disposed of in the EAV. The guidelines applicable to the Low Activity Waste Vault (LAWV), that portion of the EAV reserved for low activity waste, will be used for comparison since they are the most restrictive of the EAV facilities. Low activity waste is defined as waste that will produce less than or equal to $200 \mathrm{mR} / \mathrm{hr}$ at $5 \mathrm{~cm}$ from an unshielded final disposal container. The concentration of each radionuclide in the F- and H-Area Tank Farm supernate waste stream (Table 3.3) and their corresponding LAWV limits (Reference 5) are compared in Table 3.4. Calculations supporting this comparison are in Attachment 11. LAWV limits are expressed in $\mathrm{Ci} / \mathrm{ft}^{3}$ waste and $\mathrm{Ci} / 90 \mathrm{ft}^{3} \mathrm{~B}-25$ container.

\begin{tabular}{|c|c|c|c|c|}
\hline Radionuclide & $\begin{array}{l}\text { Supernate } \\
\text { (Ci/gal) }\end{array}$ & $\begin{array}{l}\mathrm{LAWV} \text { Limit } \\
\left(\mathrm{Ci} / \mathrm{ft}^{3}\right)^{-}\end{array}$ & $\begin{array}{l}\text { LAWV Limit } \\
(\mathrm{Ci} / \mathrm{B}-25)\end{array}$ & $\begin{array}{l}\text { Gallons of } \\
\text { supernate in } \\
\text { B-25 to reach } \\
\text { LAWV limit }\end{array}$ \\
\hline 3 & $\mathrm{~A}$ & $\mathrm{~B}$ & $\mathrm{C}=\mathrm{B} * 90 \mathrm{ft} 3 / \mathrm{B}-25$ & $\mathrm{D}=\mathrm{C} / \mathrm{A}$ \\
\hline $\mathrm{H}-3$ & $1.59 \mathrm{E}-02$ & $1.10 \mathrm{E}+01$ & $9.90 \mathrm{E}+02$ & $6.22 \mathrm{E}+04$ \\
\hline C-14 & $9.48 \mathrm{E}-06$ & $2.50 \overline{\mathrm{E}}-05$ & $2.25 \mathrm{E}-03$ & $2.37 \mathrm{E}+02$ \\
\hline Tc-99 & $9.64 \mathrm{E}-04$ & $5.60 \mathrm{E}-05$ & $5.04 \mathrm{E}-03$ & $5.23 \mathrm{E}+00$ \\
\hline $\mathrm{I}-129$ & $9.98 \mathrm{E}-07$ & $1.10 \mathrm{E}-08$ & $9.90 \mathrm{E}-07$ & $9.92 \mathrm{E}-01$ \\
\hline $\mathrm{U}-234$ & $4.73 \mathrm{E}-07$ & $1.10 \mathrm{E}-03$ & $9.90 \mathrm{E}-02$ & $2.09 \mathrm{E}+05$ \\
\hline $\mathrm{U}-238$ & $2.05 \mathrm{E}-07$ & $1.20 \mathrm{E}-03$ & $1.08 \mathrm{E}-01$ & $5.28 \mathrm{E}+05$ \\
\hline
\end{tabular}

From the container limits, the maximum volume of supernate that could be present in a $\mathrm{B}-25$ container while still meeting the LAWV limits can be calculated. The most limiting isotope in waste stream FHW00001 is $\mathrm{I}-129$, for which more than 1 gallon of supernate in a B-25 would cause the waste to exceed the LAWV limit. Supernate in the F- and H-Area Tank Farms has an average total activity of $10 \mathrm{Ci} / \mathrm{gallon}$ and a total transuranic isotope activity of $1.18 \mathrm{E}-02 \mathrm{Ci}$; accordingly, 1 gallon of supernate would be equivalent to $10 \mathrm{Ci}$ in a $\mathrm{B}-25,0.01 \mathrm{Ci}$ of which are transuranics. Per Table 3.5 below, a B-25 container with less than $258 \mathrm{lb}$. of waste and 1 gallon or more of supernate will fail TRU limits at the LAWV limit for I-129. At the maximum waste weight for a B-25 container $(5000 \mathrm{lb})$ and the presence in the waste of the maximum volume ( 1 gallon) of supernate to meet the LAWV limit for $\mathrm{I}-129$, the waste would be well within $(5 \mathrm{nCi} / \mathrm{g}$ ) the TRU limit of $100 \mathrm{nCi} / \mathrm{g}$. In practice, very few waste boxes fail TRU limits. Any such box will, upon entry into WITS, be flagged as TRU and not be sent to the LAWV.

\begin{tabular}{|c|c|c|c|c|c|c|}
\hline \multicolumn{7}{|c|}{$\begin{array}{l}\text { Table } 3.5 \text { Comparison of Maximum Amount of Supernate } \\
\text { Present to Meet LAWV limits vs. TRU Criteria }\end{array}$} \\
\hline $\begin{array}{l}\text { Max gals } \\
\text { supernate } \\
\text { B-25 to } \\
\text { meet } \\
\text { LAWV } \\
\text { criteria }\end{array}$ & $\begin{array}{l}\text { Ayerage } \\
\text { total Cil } \\
\text { gallon } \\
\text { supernate }\end{array}$ & $\begin{array}{l}\text { Average } \\
\text { total Ci / } \\
\text { B-25 at } \\
\text { LAWV } \\
\text { limit }\end{array}$ & $\begin{array}{l}\text { Average } \\
\text { total TRU } \\
\text { CII } \\
\text { gallon } \\
\text { supernate }\end{array}$ & $\begin{array}{c}\text { Average } \\
\text { total TRU } \\
\text { Ci/ B-25 } \\
\text { at } \\
\text { LAWV } \\
\text { limit }\end{array}$ & $\begin{array}{c}\text { TRU nCi/g } \\
\text { at maximum } \\
\text { waste weight } \\
(5000 \text { ib) } \\
\text { in a B -25 at } \\
\text { LAWV limit }\end{array}$ & $\begin{array}{l}\text { Minimum } \\
\text { waste weight } \\
\text { in B-25 to not } \\
\text { be TRU waste } \\
\text { (lb) }\end{array}$ \\
\hline $\mathrm{A}$ & $B$ & $C=A * B$ & $\mathrm{D}$ & $\mathrm{E}=(\mathrm{D} / \mathrm{B})^{*} \mathrm{C}$ & $\begin{array}{c}=(\mathrm{E} * 1 \mathrm{E}+09 \mathrm{nCj} \\
\mathrm{Ci}) /(5000 \\
1 \mathrm{~b} * 454 \mathrm{~g} / \mathrm{b})\end{array}$ & $\begin{array}{c}(\mathrm{E} * \mathrm{~EB}+09 \mathrm{nC} \\
/ \mathrm{Ci}) /(454 \\
\mathrm{g} / \mathrm{b} * 100 \\
\mathrm{nCl} / \mathrm{g})\end{array}$ \\
\hline $9.92 \mathrm{E}-01$ & $1.00 \mathrm{E}+01$ & $9.96 \mathrm{E}+00$ & $1.18 \mathrm{E}-02$ & $1.17 \mathrm{E}-02$ & $5.17 \mathrm{E}+00$ & $2.58 \mathrm{E}+02$ \\
\hline
\end{tabular}

Note: Average total activity of supernate from Attachment 8 and $11=1.00 \mathrm{E}+01 \mathrm{Ci} / \mathrm{gal}$. Average total TRU activity of supernate from Attachments 8 and $11=1.18 \mathrm{E}-02 \mathrm{Ci} / \mathrm{gal}$. 


\subsubsection{Sum-of-Fractions Calculation}

For acceptance of waste packages sent to the LAWV, the radiological content of the waste package must be compared to the administrative guidelines and shown to satisfy the sum-of-fractions criteria where:

activity concentration of isotope $\mathrm{A} /$ /imit of isotope $\mathrm{A}$

+ activity concentration of isotope B/limit of isotope B......

+ activity concentration of isotope $N$ /limit of isotope $N$

$\leq 1$

Attachment 11 and Table 3.6 calculate the maximum concentration of supernate on supernate-contaminated waste in order for the sum-of-the-fractions criteria to be met.

\begin{tabular}{|c|c|c|c|c|c|c|}
\hline Radionuclide & $\begin{array}{c}\text { Ci/gal } \\
\text { supernate }\end{array}$ & $\begin{array}{c}\mathrm{Ci} / \mathrm{ft}^{3} \\
\text { supernate }\end{array}$ & $\begin{array}{c}\mathrm{ft}^{3} \text { supernate } \\
\mathrm{ft}^{3} \text { waste }\end{array}$ & $\begin{array}{l}\mathrm{Cl}^{3} \mathrm{ft}^{3} \\
\text { waste }\end{array}$ & $\begin{array}{c}\text { LAWV Limit } \\
\left(\mathrm{Cu} / \mathrm{ft}^{3}\right)\end{array}$ & Fraction \\
\hline & $\mathrm{A}$ & $\mathrm{B}=\mathrm{A} * 7.48$ & $\mathrm{C}$ & $\mathrm{D}=\mathrm{B} * \mathrm{C}$ & $\mathrm{E} / \mathrm{E}$ & $=\mathrm{D} / \mathrm{E}$ \\
\hline $\mathrm{H}-3$ & $1.59 \mathrm{E}-02$ & 1.19E-01 & $1.23 E-03$ & $1.47 \mathrm{E}-04$ & $1.10 \mathrm{E}+01$ & $1.33 \mathrm{E}-05$ \\
\hline $\mathrm{C}-14$ & $9.48 \mathrm{E}-06$ & $7.09 \mathrm{E}-05$ & $1.23 \mathrm{E}-03$ & $8.74 \mathrm{E}-08$ & $2.50 \mathrm{E}-05$ & $3.50 \mathrm{E}-03$ \\
\hline Tc-99 & $9.64 \mathrm{E}-04$ & $7.21 \mathrm{E}-03$ & $1.23 \mathrm{E}-03$ & $8.89 \mathrm{E}-06$ & $5.60 \mathrm{E}-05$ & $1.59 \mathrm{E}-01$ \\
\hline I-129 & $9.98 \mathrm{E}-07$ & $7.46 \mathrm{E}-06$ & $1.23 \mathrm{E}-03$ & $9.20 \mathrm{E}-09$ & $1.10 \mathrm{E}-08$ & $8.36 \mathrm{E}-01$ \\
\hline U-234 & $4.73 \mathrm{E}-07$ & $3.54 \mathrm{E}-06$ & $1.23 \mathrm{E}-03$ & $4.36 \mathrm{E}-09$ & $1.10 \mathrm{E}-03$ & $3.97 \mathrm{E}-06$ \\
\hline $\mathrm{U}-238$ & $2.05 \mathrm{E}-07$ & $1.53 \mathrm{E}-06$ & $1,23 \mathrm{E}-03$ & $1.89 \mathrm{E}-09$ & $1.20 \mathrm{E}-03$ & $1.57 \mathrm{E}-06$ \\
\hline & & & & \multicolumn{2}{|c|}{ Sum-of-Fractions } & $9.99 \mathrm{E}-01$ \\
\hline
\end{tabular}

Tc-99 and I-129 dominate the sum-of-the-fractions for supernate waste stream FHW-00001. Primarily based on this dominance, the sum-of-fractions criteria are met for a maximum of $1.23 \mathrm{E}-03 \mathrm{ft}^{3}$ of supernate (Table 3.6) for each $1 \mathrm{ft}^{3}$ of waste, which equates to $1.11 \mathrm{E}-01 \mathrm{ft}^{3}\left(1.23 \mathrm{E}-03 \mathrm{ft}^{3}\right.$ supernate $/ \mathrm{ft}^{3}$ waste $\mathrm{x} 90 \mathrm{ft}^{3}$ maximum waste volume per B-25) or $8.30 \mathrm{E}-01$ gallon of supernate per $90 \mathrm{ft}^{3}$ volume $\mathrm{B}-25$ container. Since the mean total activity and the mean total transuranic activity for supernate are, respectively, $10 \mathrm{Ci} / \mathrm{gal}$ and $1.18 \mathrm{E}-02 \mathrm{Ci} / \mathrm{gal}$, this is equivalent to 8.3 total $\mathrm{Ci}$ of supernate in a B-25, or $9.81 \mathrm{E}-03 \mathrm{Ci}$ of transuranic isotopes in a B-25 for this waste stream. Any B-25 waste container containing 9.81E-03 Ci (or 9.81E+06 $\mathrm{nCi}$ ) of transuranics must contain $9.81 \mathrm{E}+04 \mathrm{~g}$ (or $216 \mathrm{lbs}$ ) or more of waste (out of the $5,000 \mathrm{lb}$ limit) in order to be within the TRU limit of $100 \mathrm{nCi} / \mathrm{g}$ total transuranics. A B-25 container with less than $216 \mathrm{lbs}$ of waste and 0.83 gallons or more of supernate will fail the TRU limits. At the maximum waste weight for a B-25 container $(5000 \mathrm{lb})$ and the presence in the waste of the maximum volume ( 0.83 gallon) of supernate to meet the LAWV sum-of-fractions criteria, the waste would be well within $(4.3 \mathrm{nCi} / \mathrm{g})$ the TRU limit of $100 \mathrm{nCi} / \mathrm{g}$. In practice, very few waste containers fail TRU limits. Any such container will, upon entry into WITS, be flagged as TRU and not be sent to the LAWV.

\begin{tabular}{|c|c|c|c|c|c|}
\hline \multicolumn{6}{|c|}{$\begin{array}{l}\text { Table 3.7. Comparison of Maximum Amount of Supernate Present to } \\
\text { Meet LA WV Sum-of-Fractions Limits vs. TRU Criteria }\end{array}$} \\
\hline $\begin{array}{l}\text { Maximum } \mathrm{ft}^{3} \\
\text { supernate per } \\
\mathrm{ft}^{\mathrm{t}} \text { waste to } \\
\text { meet sum-of- } \\
\text { fractions } \\
\text { criteria }\end{array}$ & $\begin{array}{l}\text { Max gals } \\
\text { supernate } 7 \\
\text { B } 25 \text { to meet } \\
\text { sum of } \\
\text { fractions } \\
\text { criteria }\end{array}$ & $\begin{array}{c}\text { Average } \\
\text { total TRU } \\
\text { Cil } \\
\text { gallon } \\
\text { supernate }\end{array}$ & $\begin{array}{l}\text { Maximum } \\
\text { total TRU } \\
\text { Ci/ B-25 } \\
\text { to meet } \\
\text { sum-of- } \\
\text { fractions } \\
\text { criteria }\end{array}$ & \begin{tabular}{|} 
Minimum lb \\
waste weight $/$ \\
B - 25 to \\
meet JRU \\
limit of \\
100 nCi/g
\end{tabular} & $\begin{array}{l}\text { TRU nCi/g in B- } \\
25 \text { to meet sum of } \\
\text { fractions criteria } \\
\text { at } 5000 \text { ib } \\
\text { maximum waste } \\
\text { weight }\end{array}$ \\
\hline & $\begin{array}{c}\mathrm{B}=\mathrm{A}^{*} 90 \mathrm{f}^{3} / \mathrm{B} \\
25+7,48 \\
\mathrm{gal} / \mathrm{ft}^{3}\end{array}$ & & $\mathrm{D}-\mathrm{B} * \mathrm{C}$ & $\begin{array}{l}=\left(\mathrm{D}^{*} 1 \mathrm{E}+09 \mathrm{nCl} / \mathrm{Ci}\right) / \\
(100 \mathrm{nCl} / \mathrm{g} * 454 \mathrm{~g} / \mathrm{b})\end{array}$ & $\left(\mathrm{D}^{*} \mathrm{lE}+09 \mathrm{nClCi}\right)$ \\
\hline $1.23 \mathrm{E}-03$ & $8.30 \mathrm{E}-01$ & $1.18 \mathrm{E}-02$ & $9.81 \mathrm{E}-03$ & $2.16 \mathrm{E}+02$ & $4.32 \mathrm{E}+00$ \\
\hline
\end{tabular}




\subsubsection{Nuclear Criticality Safety Criteria}

Sludge-contaminated LLW contains an insignificant quantity of fissionable material to impact nuclear criticality criteria. Attachment 11 and Table 3.8 determine the maximum quantity of sludge that could be placed in a B-25 prior to exceeding the 50-g Fissile Gram Equivalent (FGE) U-235 limit for the LAWV. This is equivalent to 713 gallons of supernate, a significantly greater volume than would meet LAWV and TRU waste limits for a B-25 waste container. Any such box will not be sent to the LAWV for disposal, therefore protecting this requirement.

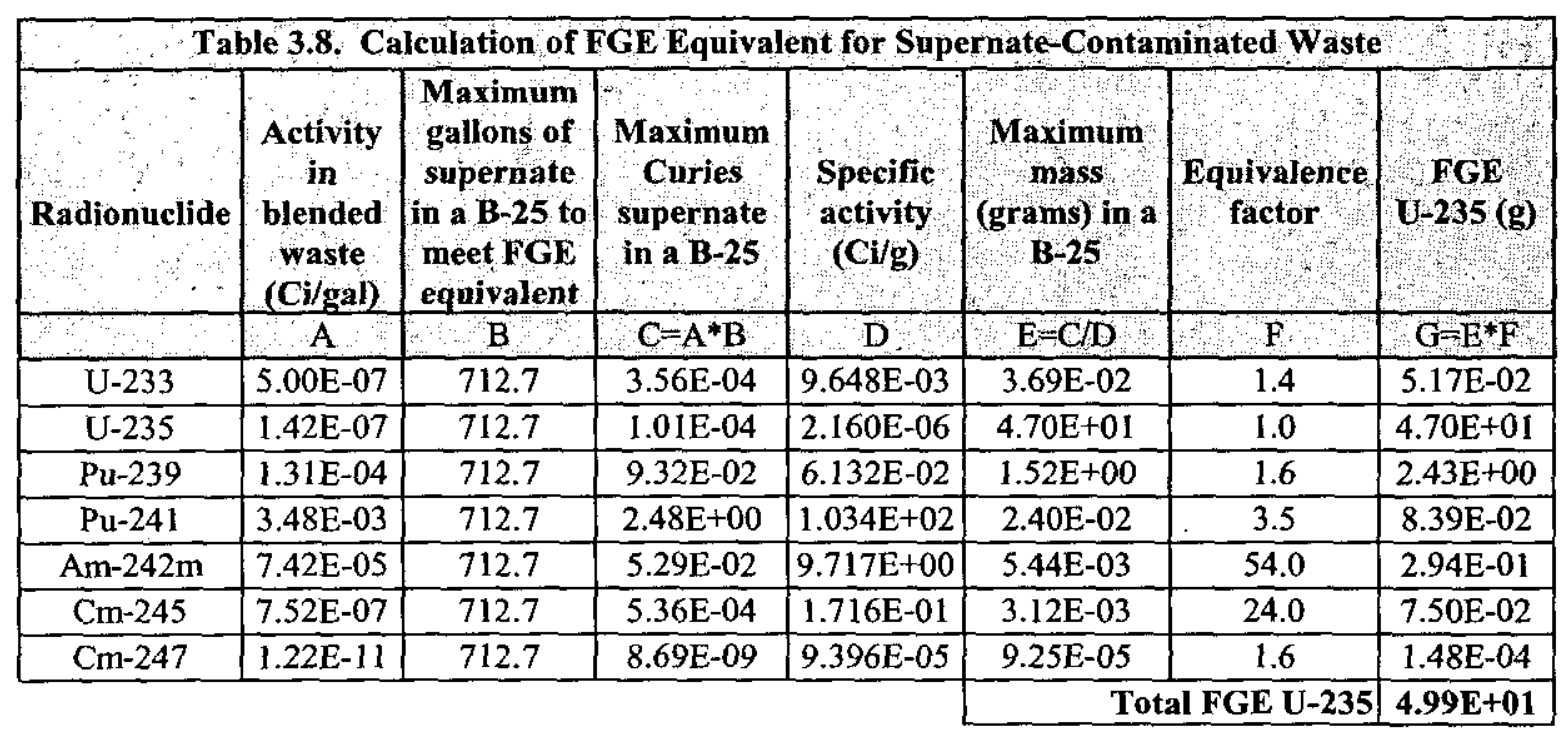

\subsection{Documentation of the Supernate Distribution}

A low level waste stream form for F- and H-Area Tank Farm Waste Stream, FHW-00001, included as Attachment 12, documents the distribution for F- and H-Area Tank Farms supernate waste. For those packages determined to contain sufficient supernate to be determined mixed and/or transuranic, appropriate waste stream forms will be provided for each package.

\subsection{Periodic Validation}

Provisions of Procedure WAC 2.02, Revision 7 (Reference 3), require generators of routine wastes to review and confirm the certification of each waste stream at least periodically. Waste stream FHW-00001 is on a five-year schedule. 
1. Ketusky, E. T. and R. F. O'Bryant, "HLW Supernate Radionuclide Characterization," WSRCTR-94-0290, Revision 3, April 19, 1999.

2. Hester, J. R., "High Level Waste Characterization System (WCS)," WSRC-TR-96-0264, Revision 0, December 1996.

3. Procedure WAC 2.02, "Low Level Waste Characterization Requirements," WSRC is Savannah River Site Waste Acceptance Criteria Manual, Revision 7, Savannah River Site, November 1, 2002.

4. Ross, R. H., E. T. Ketusky, E. T., R. Petras, and L. E. Rykken, "HLW Characterization in Support of Low Level Waste Certification: HLW Sludge Beta Screening Tool," WSRC-TR97-0555, Revision 2, March 2003.

5. Procedure WAC 3.17, "Low Level Waste Acceptance Criteria," WSRC 1S Savannah River Site Waste Acceptance Manual, Revision 7, Savannah River Site, September 16, 2002.

6. O'Bryant, R. F. and W. R. Weiss, "Characterization of Radionuclides in H-Modified and Purex Waste Sludges from H-Area High Level Waste Tanks (U)," WSRC-TR-2000-00249, Revision 2, March 2003.

7. O'Bryant, R. F. and J. K. W. Dunaway, "Characterization of Radionuclides in Purex Waste Sludges from F-Area High Level Waste Tanks (U)," WSRC-TR-2000-00215, Revision 1, January 2003. 


\section{Attachment 1}

F- and H-Area Tank Farms WCS Tank Data 


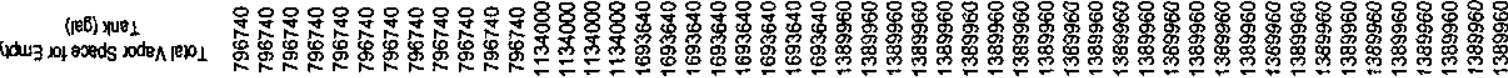

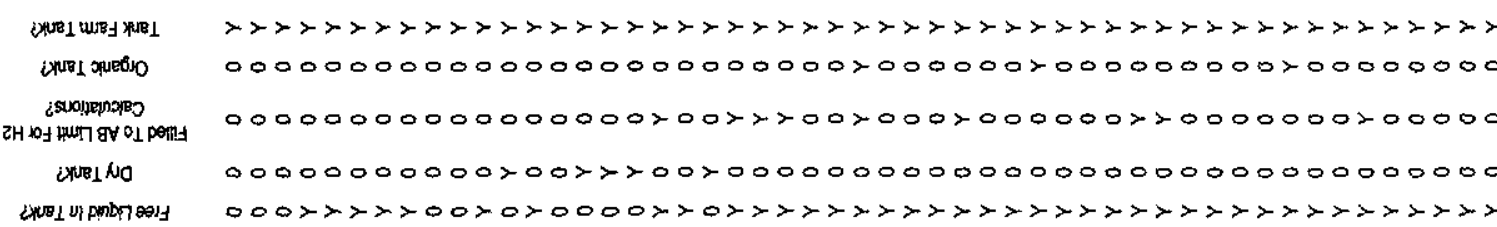

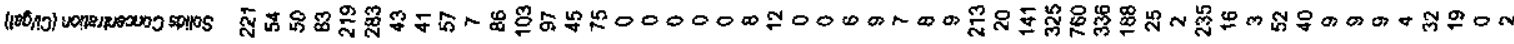

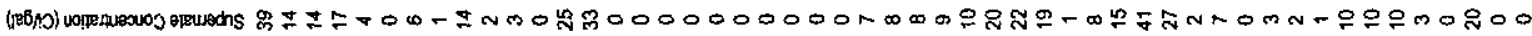

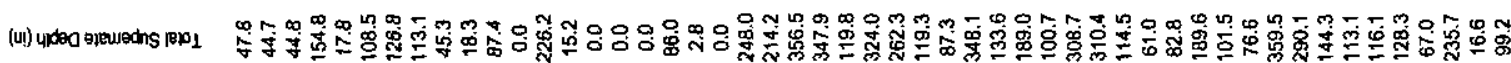

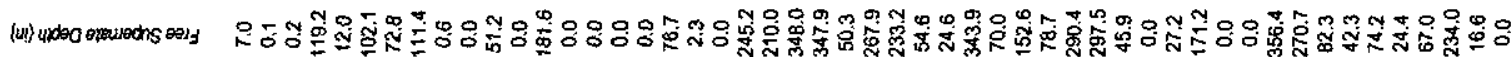

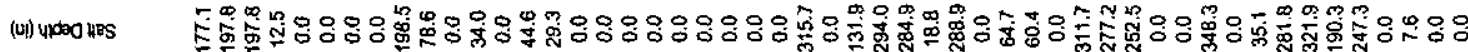

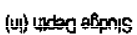

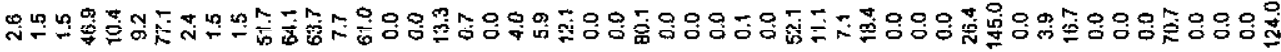

(b)

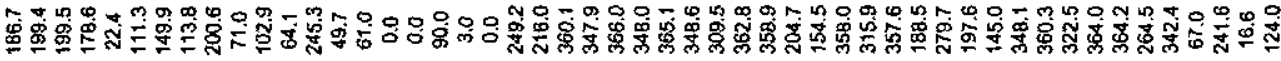

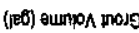

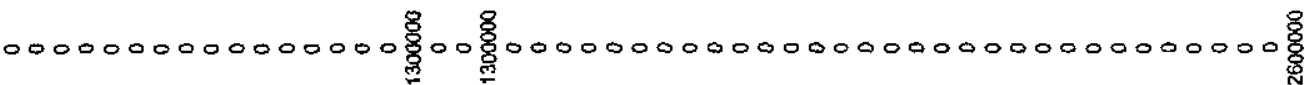

(5x) Mค์|ำM 1803 $000000 \frac{\infty}{6} 00000000000000000000000000000000000000000000 \frac{0}{5}$

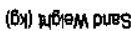

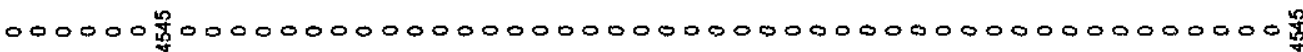

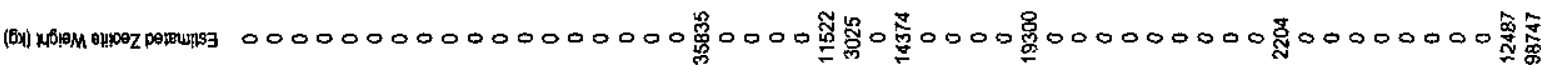

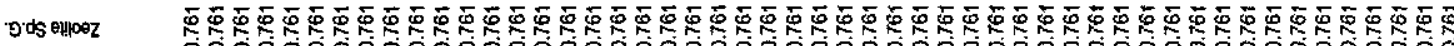

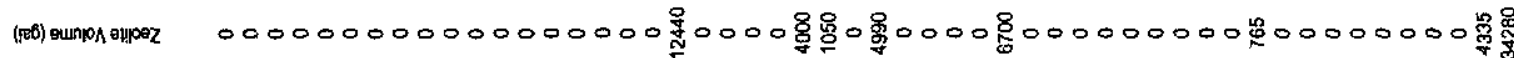

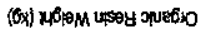

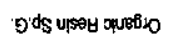
0000000000000000000000000000000000000000000000000000

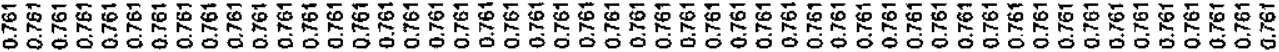

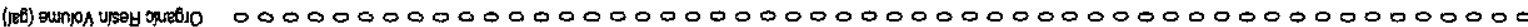

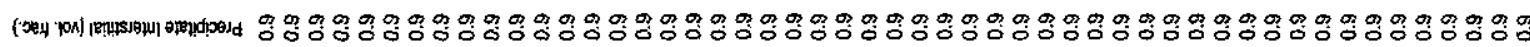

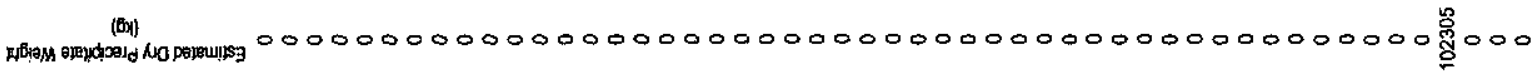

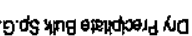

(ieb) eunpr opaydjold

ods eneuechs

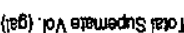

(18) man

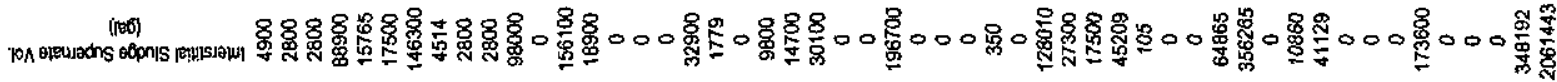

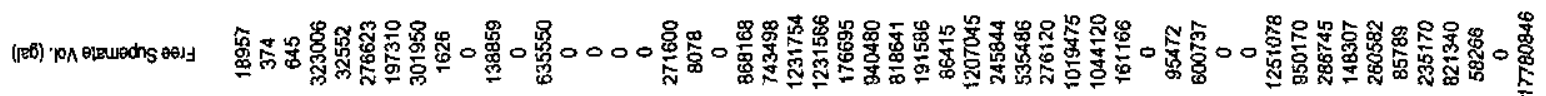

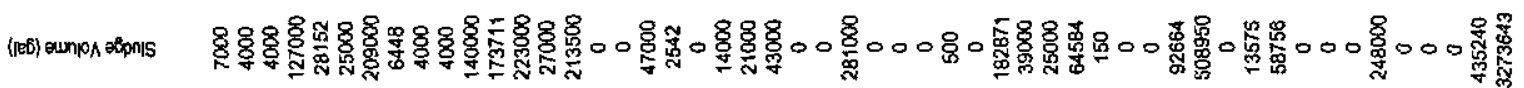

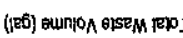

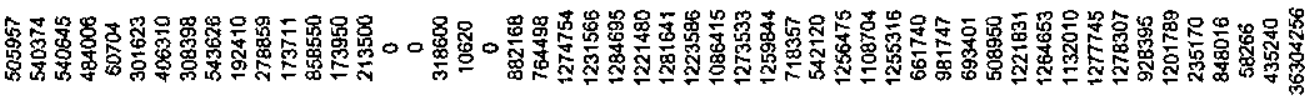

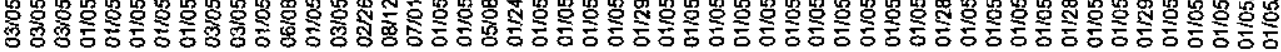


Attachment 2

F- and H-Area Tank Farms WCS Supernate Inventory 


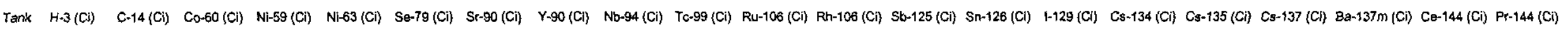

$2.57 E+06 \quad 2.43 E+06$

8.91E+05 $\quad 8.42 \mathrm{E}+05$

$\begin{array}{ll}8.93 E+05 & 8.44 E+05 \\ 3.69 E+06 & 3.49 E+06\end{array}$

6.71E+04 $8.24 E+04$

$1.07 \mathrm{E}+04 \quad 1.01 \mathrm{E}+04$

$1.01 E+06 \quad 9.55 E+05$

$1.10 E+05 \quad 1.04 E+05$

$8.85 E+05 \quad B .37 E+05$

B.25E+04 5.91E+04

$3.09 E+05 \quad 2.92 E+05$

$0.00 E+\infty 0000 E+00$

$1.03 E+07 \quad 9.79 E+00$

$8.89 E+05 \quad 8.41 E+05$

$0.00 E+\infty O) 0.00 E+\infty$

$0.00 E+00 \quad 0.00 E+00$

$5.82 \mathrm{E}+03 \quad 550 \mathrm{E}+03$

$1.88 \mathrm{E}+02 \quad 1.78 \mathrm{E}+02$

$0.00 E+\infty 00.00 E+\infty$

$4.08 \mathrm{E}+03 \quad 3.86 \mathrm{E}+03$

$1.78 \mathrm{E}+03 \quad 1.68 \mathrm{E}+03$

$1.74 E+02 \quad 1.65 E+02$

$1.84 E+03 \quad 1.74 E+03$

$1.49 E+06 \quad 1.41 E+06$

$4.81 E+06 \quad 4,55 E+06$

$3.75 E+06 \quad 3.55 E+06$

$1.87 E+06 \quad 1.77 E+06$

$1.56 \mathrm{E}+06 \quad 1.48 \mathrm{E}+06$

$1.26 E+07 \quad 1.21 E+07$

$5.32 E+06 \quad 5.04 E+06$

$6.44 E+06 \quad 6.09 E+06$

$1.82 E+05 \quad 1,72 E+05$

$8.43 \mathrm{E}+06 \quad 7.97 \mathrm{E}+06$

$8.40 E+06 \quad 7.95 E+06$

$294 \mathrm{E}+06 \quad 2.78 \mathrm{E}+06$

$2.81 \mathrm{E}+05 \quad 2.65 \mathrm{E}+05$

$2.38 \mathrm{E}+06 \quad 2.25 \mathrm{E}+06$

$3.73 \mathrm{E}+03 \quad 3.53 \mathrm{E}+03$

4.20E+05 3.97E+05

$1.21 E+06 \quad 1.15 E+06$

$7.75 E+05 \quad 7.33 E+05$

2.68E+06 2.54E+06

$1.99 \mathrm{E}+06 \quad 1.88 \mathrm{E}+06$

$2.07 \mathrm{E}+06 \quad 1.96 \mathrm{E}+06$

$7.31 \mathrm{E}+05 \quad 6.92 \mathrm{E}+05$

$1.41 E+04 \quad 1.33 E+04$

8. $59 \mathrm{E}+06 \quad 8.12 \mathrm{E}+06$

$1.22 E+00 \quad 1.15 E+\infty$

:.05E+08 $9.95 E+07$ 


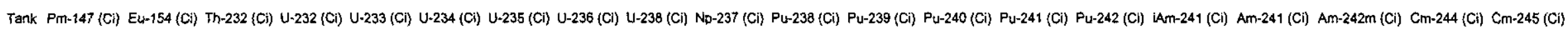

\begin{tabular}{|c|c|c|c|c|c|c|c|c|c|c|c|c|c|c|c|c|c|}
\hline & $545 E-05$ & & & $241 E-04$ & & $581 E-03$ & 5.33E-03 & $1.54 E+01$ & $2.33 E+00$ & $5.56 \mathrm{E}-01$ & $4.52 E+00$ & $1.79 E-04$ & $8.19 E-01$ & $8.06 \mathrm{E}+00$ & $1,01 E-02$ & $1.59 E-03$ & $1.84 E-09$ \\
\hline & $5,10 E-05$ & & & $2.25 \varepsilon-04$ & & $5.44 E-03$ & $4.99 E-03$ & $1.44 E+01$ & $2.18 E+\infty 0$ & 5.20E-01 & $4.23 E+\infty$ & $1.68 \mathrm{E}-04$ & 7.66E-01 & $7.54 \mathrm{E}+\infty$ & $9.46 \mathrm{E}-03$ & $1,49 E-03$ & $1.72 \mathrm{E}-09$ \\
\hline & $5.11 E-05$ & & & $2.26 E-04$ & & 5.45E-03 & $5.00 E-03$ & $1.44 \mathrm{E}+01$ & $2.18 E+00$ & $5.21 \mathrm{E}-01$ & $4.24 E+\infty 0$ & 1.68E-04 & $7.68 E-01$ & $7.55 E+00$ & $9.48 E-03$ & $1.49 E-03$ & $1.72 E-09$ \\
\hline & $4,96 \mathrm{E}-04$ & & & $5.38 E-04$ & & 2.32E-02 & $2.07 E-02$ & $4.99 \mathrm{E}+00$ & $4.14 E+\infty 0$ & $9.26 \mathrm{E}-01$ & $8.89 \mathrm{E}++0$ & $1.90 \mathrm{E}-04$ & i. $21 \mathrm{E}+00$ & $7.75 \mathrm{E}+01$ & $1.00 \mathrm{E}-01$ & 2.22E-02 & 1.67E- 08 \\
\hline & 4.48E-05 & & & 8.24E- 05 & & $1.95 E-03$ & $3.30 E-03$ & $2.27 \mathrm{E}+\infty$ & $3.79 E-01$ & $9.06 \varepsilon-02$ & 6.89E-01 & $2.67 E-05$ & 1.35E-01 & $7.26 \mathrm{E}+00$ & $9.25 E-03$ & 1. $65 E-03$ & $1.58 E-09$ \\
\hline & $3.69 E-04$ & & & $3.97 \varepsilon-04$ & & $1,48 E-02$ & $5.15 E-03$ & & $1.52 E+\infty$ & $5.28 \mathrm{E}-01$ & $6.73 E+\infty 0$ & $1.04 E-03$ & $1.03 E+00$ & $5.86 E+01$ & $7.56 E-02$ & $1.52 E-02$ & 1.26E-08 \\
\hline & $1.45 \mathrm{E}-04$ & & & 6.39E- -04 & & 1. $54 E-02$ & $1.41 E-02$ & $4.09 E+01$ & 8.18E+00 & $1.48 \mathrm{E}+00$ & $1.20 E+01$ & $4.76 E-04$ & $2.17 E+\infty 0$ & $2.14 E+01$ & $2.68 E-02$ & $4.22 \mathrm{E}-03$ & $488 \mathrm{~B}-09$ \\
\hline & $1.67 E-04$ & & & $3.86 E-04$ & & $1.78 E-02$ & $8.07 E-03$ & $3.23 E+01$ & $5.07 E+\infty$ & 1. $19 \mathrm{E}+\infty$ & $1.29 \mathrm{E}+01$ & $1.51 \mathrm{E}-03$ & $1.22 E+00$ & $2.45 E+01$ & 3.17E-02 & $6.82 E-03$ & $5.39 E-09$ \\
\hline $6.68 \mathrm{E}-05$ & $1.87 E-05$ & $1.37 \mathrm{E}-02$ & $1.93 E-03$ & $5.28 \mathrm{E}-05$ & $1.99 E-04$ & 6.17E-04 & $4.97 E-03$ & $1.87 E+01$ & $4.91 E-01$ & $2.03 E-01$ & $4.07 E+00$ & 1.35E-04 & 7.52E-01 & $5.57 E+00$ & $6.76 E-03$ & $1.53 \mathrm{E}-02$ & $2.02 E-06$ \\
\hline $70 E-05$ & $7,56 E-06$ & $5.54 E-03$ & 7.81E-04 & 2.14E-05 & $8.05 E-05$ & $2.50 E-04$ & 2.01E-03 & $7.58 E+00$ & $1.99 E-01$ & 8.22E-02 & $1.64 E+00$ & 5.45E-05 & $3.04 E-01$ & $2.25 E+\infty$ & $2.73 E-03$ & 6.20E-03 & 8.15E-07 \\
\hline $4.235-06$ & $4.91 E-08$ & $6.03 E-04$ & 4.95E-0A & Q.33E-06 & $7.65 E-05$ & $1,73 E-05$ & $3.27 \mathrm{E}-04$ & $4,52 \mathrm{E}+04$ & A.39E-O1 & $2.76 E-01$ & $1.70 E \times 01$ & 5.97E- -94 & $1.76 E+\infty$ & $2.105 \div 00$ & $2.50 E-03$ & $1.44 E-02$ & $1.60 E=06$ \\
\hline $4.31 E-04$ & $1.20 E-04$ & $8.82 E-02$ & $1.25 E-02$ & $3.40 \mathrm{E}-04$ & $1.28 \mathrm{E}-03$ & $3.98 E-03$ & $3.20 E-02$ & 1.21E+02 & 3. $17 E+\infty 0$ & $1.31 E+00$ & $2.62 E+01$ & $8.69 \mathrm{E} .04$ & $4.85 E+00$ & $3.59 E+01$ & 4.36E-02 & $9.88 \mathrm{E}-02$ & $1.30 \mathrm{E}-05$ \\
\hline $1.20 \mathrm{E}-04$ & $3.66 E-05$ & $4.24 E-03$ & $5.82 E-04$ & $4.71 \mathrm{E}-05$ & $5.01 \mathrm{E}-05$ & $8.98 E-04$ & $6.22 E-03$ & $2.84 \mathrm{E}+00$ & 6.86E-01 & 2.22E-01 & $1.27 E+\infty$ & $4.06 E .05$ & $2.76 \mathrm{E}-01$ & $7.13 E+\infty$ & $8.85 E-03$ & $5.26 E-03$ & $6.93 E-07$ \\
\hline & $2.94 E-05$ & & & $2.23 E-04$ & & $1.20 \mathrm{E}-02$ & & $5.11 E+01$ & $7.30 E+\infty 0$ & $1.86 E+00$ & $3.41 \mathrm{E}+01$ & 2.39E-03 & $3.69 E+\infty$ & & & $3.70 E-04$ & $2.90 \mathrm{E}-10$ \\
\hline & 5.31E-07 & & & 3.50E- $-\infty$ & & 3.20E-04 & & $1.31 \varepsilon+\infty$ & 1.88E-01 & 4.19E-02 & $5.45 E+\infty 0$ & 8.63E-05 & $5.26 \mathrm{E}-01$ & & & $7.56 \mathrm{E}-06$ & $5.01 \mathrm{E}-12$ \\
\hline 1.04E-06 & & $3.19 E-02$ & 3.15E-02 & 4.34E-04 & 6.44E-03 & 2.94E-04 & $1.94 E-02$ & $1.75 E+02$ & 2.02E-01 & $1.17 E-01$ & $4.35 \mathrm{E}+00$ & $9.81 E-05$ & $5.02 E-01$ & $8.40 E+00$ & $1.01 E-02$ & 9.60E-02 & $8.64 E-06$ \\
\hline & & $9.94 \mathrm{E}-02$ & $3.57 \mathrm{E}-02$ & $5.46 E-04$ & $5.88 \mathrm{E}-03$ & $7.95 \mathrm{E}-04$ & $2.17 \mathrm{E}-02$ & $1,50 E+02$ & & & & & & $8.69 E+\infty 0$ & $1.05 E-02$ & $1.01 \mathrm{E}-01$ & $9.19 E-06$ \\
\hline & $1,44 E-03$ & & & $3.27 E-03$ & & $2.99 \mathrm{E}-01$ & & $2.48 E+03$ & $3.54 E+02$ & $7.90 E+01$ & $1.96 \mathrm{E}+03$ & $1.63 \mathrm{E}-02$ & $7.66 \mathrm{E}+01$ & & & $2.88 \mathrm{E}-02$ & $1.21 \mathrm{E}-08$ \\
\hline & $3.89 E-03$ & & & 8.84E- -03 & & 8.08E-01 & & $6.70 E+03$ & $9.56 E+02$ & $2.14 E+02$ & $5.29 E+03$ & $4.40 E-02$ & $2.07 E+02$ & & & $7.79 E-02$ & $3.27 E-08$ \\
\hline & 3.15E-03 & & & $7.16 \mathrm{E}-03$ & & $6.54 E-01$ & & 5.42 & & 1.73E +02 & $4.28 \mathrm{E}+03$ & & & & & & \\
\hline & $1.43 E-03$ & & & 3.26E-03 & & $2.97 E-01$ & & $2.46 E+03$ & $3.52 E+02$ & $7.87 E+01$ & $1.95 E+03$ & $1,62 \mathrm{E}-02$ & $7.63 E+01$ & & & 2.87E-02 & 1.21E-08 \\
\hline $1.67 E-04$ & 4.66E-05 & $3.42 E-02$ & $4.82 E-03$ & 1.32E-04 & $4.97 \mathrm{E}-04$ & $1.54 E-03$ & $1,24 E-02$ & $4.68 E+01$ & $1.23 E+\infty 0$ & 5.07E-01 & $1.01 E+01$ & 3. $37 E-04$ & $1.88 E+00$ & $1.39 \mathrm{E}+01$ & $1.69 \mathrm{E}-02$ & 3.83E- -02 & 5.03E-06 \\
\hline $6.65 E-04$ & $1.86 E-04$ & $1.36 \mathrm{E}-01$ & $1.92 E-02$ & $5.25 \mathrm{E}-04$ & 1.98E-03 & $6.14 E-03$ & $\begin{array}{l}4.94 E-02 \\
\end{array}$ & $1.86 E+02$ & $4.89 E+\infty 0$ & $2.02 E+00$ & $4.05 E+01$ & 1.34E-03 & $7.48 E+\infty 0$ & $5.54 E+01$ & 6.73E-02 & $3 E-01$ & $2.01 \mathrm{E}-05$ \\
\hline 2.55E-04 & 7.14E-05 & 5.23E-02 & 7.37E-03 & $2.02 E-04$ & 7.60E-04 & $2.36 \mathrm{E}-03$ & $1.90 \mathrm{E}-02$ & $7.15 \mathrm{E}+01$ & $1.88 \mathrm{E}+\infty 0$ & 7.76E-01 & 1.55E+01 & 5.15E-04 & $2.87 \mathrm{E}+00$ & $2.13 E+01$ & $2.58 E-02$ & 5.8SE-02 & $7.70 E-06$ \\
\hline & & & $2.95 E-02$ & 4.22E- 04 & $6.61 E-03$ & $1.98 E-04$ & $1.22 E-02$ & $4.37 E+03$ & $3.75 E+01$ & $2.79 E+01$ & $2.47 E+03$ & $5.87 \mathrm{E}=02$ & $1.51 E+02$ & 1.26E +02 & $1.53 E-01$ & $1.05 E+00$ & 9.53E-05 \\
\hline & $1.02 E-02$ & $4.87 E-08$ & $4.06 \mathrm{E}-04$ & 2.19E-02 & 9.73E-03 & 3.21E+00 & $1.25 E+00$ & $2.97 \mathrm{E}+00$ & $8.98 \mathrm{E}+02$ & $1.64 E+02$ & $5.13 E+03$ & $8.38 E-03$ & $3.58 \mathrm{E}+01$ & $1.40 E+03$ & T. $.11 E+\infty$ & 6.98E-01 & $2.94 E-07$ \\
\hline & $497 \mathrm{E}-02$ & & & $4.74 E-0 ?$ & & $334 E+\infty$ & $2.58 E+\infty 0$ & & $5.40 E+02$ & $1.21 \mathrm{E}+02$ & $284 \mathrm{E}+03$ & $250 \mathrm{E}-02$ & $1.20 E+02$ & $6.90 \mathrm{E}+03$ & $9,35 E+\infty 0$ & $E+\infty$ & $145 E-06$ \\
\hline & & & $4.72 E-02$ & 8.20E-04 & 1.39E-02 & $4.84 E-04$ & 1.71E-02 & $7.22 E+03$ & $5.72 \mathrm{E}+01$ & $4.38 \mathrm{E}+01$ & $3.86 E+03$ & $9.82 E-02$ & $2.38 \mathrm{E}+02$ & $1.74 \mathrm{E}+02$ & 2.13E-01 & 1. $65 E+\infty 0$ & $1.30 E-04$ \\
\hline 2.19E-04 & $6,12 E-05$ & $4.48 E-02$ & $\begin{array}{l}4.1<E-V L \\
8.32 E-03\end{array}$ & $\begin{array}{l}0.273 E-04 \\
1.73 E-04\end{array}$ & B.52E-04 & $2.02 E-03$ & $1.63 \mathrm{E}-02$ & & & $6.65 E-01$ & & & & $1.82 \mathrm{E}+01$ & 2.21E-02 & $5.02 E-02$ & $6.60 E-08$ \\
\hline $1.16 E-04$ & 3.26E-05 & $2,39 E-02$ & $3.37 \varepsilon-03$ & $9.21 \mathrm{E}-05$ & $3.47 E-04$ & $1.08 E-03$ & $8.66 E-03$ & 3.27E+01 & 8.57 & 3.54E-01 & $7.09 E+\infty$ & 2.35E-04 & $1.31 E+\infty$ & $9.71 E+\infty$ & & $E-02$ & $4 E-06$ \\
\hline & & & 7.47E-02 & $7.53 \mathrm{E}-04$ & $1.14 E-02$ & & $6.51 \mathrm{E}$ & & & $E+\infty$ & & & & & & & \\
\hline & & & $\begin{array}{l}4.72 E-02 \\
\end{array}$ & $2.78 E-04$ & $\begin{array}{l}4.40 E-03 \\
\end{array}$ & 2.398 & $\begin{array}{l}1.98 E-02 \\
\end{array}$ & $=+03$ & $=+01$ & $1.95 E+01$ & $2.03 E+03$ & $6.45 E-02$ & $E+01$ & $E+01$ & & $1.09 E+03$ & 8.65E-02 \\
\hline $1.95 E-03$ & $4.52 E-03$ & 1.24E-01 & 4.47E-02 & $1.27 E-02$ & $7.04 \mathrm{E}-03$ & $5.62 E-01$ & $2,33 E-01$ & $1.57 E+03$ & & $4.89 E+01$ & $5.75 E+02$ & $5.95 \mathrm{E}-02$ & & & EE-O & E-01 & 2.49E-05 \\
\hline & & & $6.92 E-02$ & $6.97 \mathrm{E}-04$ & $1.05 E-02$ & $9.80 E-05$ & 6.03E-02 & 1. $.8 B E+03$ & $5.86 E+\infty$ & $3.88 E+\infty$ & $3.03 E+02$ & $7.28 E-02$ & $6.45 E+\infty$ & $1.01 E+01$ & 1.26E-02 & $E-01$ & $1.06 \mathrm{E}-05$ \\
\hline $1.03 E-01$ & $5.53 \mathrm{E}-04$ & $1.45 E+\infty$ & 5.32E-01 & $1.26 \mathrm{E}-02$ & 3.12E-02 & 2.20E-01 & 4.38E-01 & 7.26 & 2.47 & $8.85 E+01$ & & & $E+02$ & 1.07 & & $+\infty$ & $E-04$ \\
\hline & & & $2.62 E-01$ & $2.64 \mathrm{E}-03$ & 3.99E-02 & $3.71 \mathrm{E}-04$ & 2.28E-01 & $7.13 E$ & & +01 & $E+03$ & & $2.44 E+0 t$ & $3.84 \mathrm{E}+01$ & 4.76E-02 & $E-01$ & $4.00 \mathrm{E}-05$ \\
\hline & $1.73 \mathrm{E}-03$ & & & $3.94 E-03$ & & $3.60 \mathrm{E}-01$ & & $2.98 E+03$ & $4.26 \mathrm{E}+02$ & $9.52 E+01$ & 2.35E +03 & $1.96 E-02$ & $9.23 E+01$ & & & $3.47 E-02$ & $1.46 \mathrm{E}-08$ \\
\hline & $1,36=-03$ & & & 3.09E- 03 & & Ż. BZEE-Û́ & & $2.34 E+0 \hat{3}$ & $\hat{3} .34 E+0 \hat{2}$ & 7.4. & & & & & & & $\hat{1}, \hat{i} 4 \mathrm{E}-0 \overline{8}$ \\
\hline & 1.39E-03 & & & $3.17 \mathrm{E}-03$ & & $2.90 E-01$ & & $2.40 \mathrm{E}+03$ & 3.43E+02 & $7.66 \mathrm{E}+01$ & $1.90 \mathrm{E}+03$ & $1.58 \mathrm{E}-02$ & $7.43 E+01$ & & & $2.79 E-02$ & 1.17E- 08 \\
\hline & 1.54E-03 & & & 3.50E-03 & & 3.20E-01 & & $2.65 E+03$ & $3.79 E+02$ & $8.47 E+01$ & $2.09 E+03$ & $1.74 E-02$ & $8.21 E+01$ & & & $3.08 \mathrm{E}-02$ & 1.30E-08 \\
\hline $14 E-03$ & $6.59 E-05$ & $7.00 E-01$ & $4.66 \mathrm{E}-01$ & 4.51E-03 & 1.18E-02 & $1.04 E-01$ & $2.07 E-01$ & $1.56 E+03$ & $6.93 E+02$ & $2.86 E+01$ & $3.90 \mathrm{E}+02$ & $5.97 E-02$ & $2.28 E+01$ & $1.06 \mathrm{E}+02$ & $9.01 E-02$ & $6.27 E+01$ & $6.02 E-05$ \\
\hline $14 E-01$ & $8.30 E-02$ & $2.81 E+\infty 0$ & $1.70 E+00$ & $1,46 E-01$ & $2.05 E-01$ & $1.09 E+01$ & $5.37 \varepsilon+\infty 0$ & 6.50E+04 & $6.70 E+03$ & $1.45 E+03$ & $4.24 E+04$ & $1.07 E+\infty 0$ & $1.93 E+03$ & $1.09 E+04$ & $1.45 E+01$ & $1.16 E+03$ & $8.78 E-02$ \\
\hline
\end{tabular}


WSRC-TR-2000-00290

Revision 4

Attachment 3

Calculation of Supernate Concentrations from WCS Supernate Inventory and Tank Data 
Attachment 3

Calculation of Supernate Concentrations from WCS Supernate Inventory and Tank Data

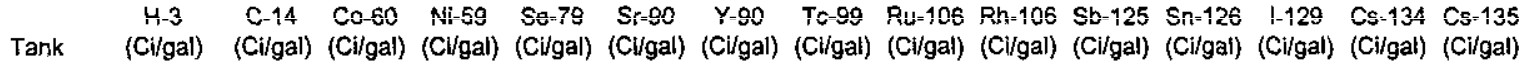

Cs-137 Ba-137m Ce-144 Pr-144 Pm-147 Eu-154 Th-232

(0.232

3

$7.35 \mathrm{E}+00 \quad 6.96 \mathrm{E}+00$

$\begin{array}{ll}7.35 \mathrm{E}+00 & 6.96 \mathrm{E}+00 \\ 7.35 \mathrm{E}+00 & 6.96 \mathrm{E}+00\end{array}$

$8.80 E+00 \quad 8.32 E+00$

$1.80 \mathrm{E}+00 \quad 1.71 \mathrm{E}+00$

3.64E-02 3.44E-02

$2.94 \mathrm{E}+00 \quad 2.78 \mathrm{E}+00$

3.59E-01 3.39E-01

$7.21 E+00 \quad 6.82 E+00$

$1.26 \mathrm{E}+00 \quad 1.19 \mathrm{E}+00$

$1.30 E+00 \quad 1.23 E+00$

$1.31 E+01 \quad 1.24 E+01$

$1.67 \mathrm{E}+01 \quad 1.58 \mathrm{E}+01$

$1.91 E-02 \quad 1.81 E-02$

$1.91 \mathrm{E}-02 \quad 1.81 \mathrm{E}-02$

4.65E-03 4.40E-03

2.34E-03 2.22E-03

$1.38 \mathrm{E}-04 \quad 1.30 \mathrm{E}-04$

$1.49 \mathrm{E}-03 \quad 1.41 \mathrm{E}-03$

$3.53 E+00 \quad 3.34 E+00$

4.23E+00 $4.00 \mathrm{E}+00$

4.07E+00 3.85E+00

$4.47 \mathrm{E}+00 \quad 4.23 \mathrm{E}+00$

$5.10 \mathrm{E}+00 \quad 4.83 \mathrm{E}+00$

$1.04 E+01 \quad 9.88 E+00$

$1.14 E+01 \quad 1.07 E+01$

$9.70 \mathrm{E}+00 \quad 9.18 \mathrm{E}+00$

5.15E-01 4.88E-01

$3.96 \mathrm{E}+00 \quad 3.75 \mathrm{E}+00$

$7.74 \mathrm{E}+00 \quad 7.32 \mathrm{E}+00$

$2.09 \mathrm{E}+01 \quad 1.98 \mathrm{E}+01$

1.37E+0̂1 1.30E+0̂1

9.66E-01 9.14E-01

$3.57 E+00 \quad 3.38 E+00$

1.05E-02 9.91E-03

$\begin{array}{ll}1.56 \mathrm{E}+00 & 1.48 \mathrm{E}+00 \\ 9.61 \mathrm{E}-01 & 9.09 \mathrm{E}-01\end{array}$

$\begin{array}{ll}9.61 \mathrm{E}-01 & 9.09 \mathrm{E}-01 \\ 7.61 \mathrm{E}-01 & 7.20 \mathrm{E}-01\end{array}$

$5.30 \mathrm{E}+00 \quad 5.01 \mathrm{E}+00$

$5.01 E+00 \quad 4.74 E+00$

$5.08 E+00 \quad 4.81 E+00$

$1.62 \mathrm{E}+00 \quad 1.54 \mathrm{E}+00$

5.98E-02 5.66E-02

$1.04 \mathrm{E}+01 \quad 9.82 \mathrm{E}+00$

2.09E-05 1.98E-05

4.49E-02 4.25E-02

4.21E-10

4.21E-10

4.21E-10

1.18E-09

9.27E-10

4.21E-10

4.21E-10

$5.44 \mathrm{E}-10 \quad 1.52 \mathrm{E}-10$

5.44E-10 1.52E-10

1.78E-11 2.07E-13

5.44E-10 $1.52 \mathrm{E}-10$

2.26E-09 $6.87 \mathrm{E}-10$

$4.85 E+00 \quad 4.59 E+00$

2.11E-08 $1.89 \mathrm{E}-10$

8.19E-09 $3.73 \mathrm{E}-09$ 
Attachment 3

Calculation of Supernate Concentrations from WCS Supernate Inventory and Tank Data

\begin{tabular}{|c|c|c|c|c|c|c|c|c|c|c|c|c|c|c|c|c|c|}
\hline Tank & $\begin{array}{l}\text { U-233 } \\
\text { (Ci/gal) }\end{array}$ & $\begin{array}{c}\text { U-234 } \\
\text { (Cilgal) }\end{array}$ & $\begin{array}{l}\text { U-235 } \\
\text { (Cilgal) }\end{array}$ & $\begin{array}{c}\text { U-236 } \\
\text { (Ci/gal) }\end{array}$ & $\begin{array}{l}\text { U-238 } \\
\text { (Cival) }\end{array}$ & $\begin{array}{l}\text { Np-237 } \\
\text { (Cilgal) }\end{array}$ & $\begin{array}{l}\text { Pu-238 } \\
\text { (Ci/gal) }\end{array}$ & $\begin{array}{l}\text { Pu-239 } \\
\text { (Cl/gal) }\end{array}$ & $\begin{array}{l}\text { Pu-240 } \\
\text { (Ci/gal) }\end{array}$ & $\begin{array}{l}\text { Pu-241 } \\
\text { (Ciigal) }\end{array}$ & $\begin{array}{l}\text { Pu-242 } \\
\text { (Cilgal) }\end{array}$ & $\begin{array}{l}\text { Ingrown } \\
\text { Am-241 } \\
\text { (Cilgal) }\end{array}$ & $\begin{array}{l}\text { Am-241 } \\
\text { (Ci/gal) }\end{array}$ & $\begin{array}{c}\text { Am-242m } \\
\text { (Ci/gal) }\end{array}$ & $\begin{array}{l}\text { Cm-244 } \\
\text { (Cil'gal) }\end{array}$ & $\begin{array}{l}\text { Cm-245 } \\
\text { (Ci/gal) }\end{array}$ & Total (Ci/gal) \\
\hline 1 & $4.21 E-10$ & & & & $1.86 \mathrm{E}-09$ & & 4.49E-08 & $4.12 E-08$ & 1.19E-04 & $1.80 \mathrm{E}-05$ & $4.29 E-06$ & $3.49 \mathrm{E}-05$ & $1.38 E-09$ & $6.33 \mathrm{E}-06$ & $6.22 \mathrm{E}-05$ & $7.81 E-08$ & $3.86 \mathrm{E}+01$ \\
\hline 2 & $4.21 E-10$ & & & & $1.86 \mathrm{E}-09$ & & $4.49 \mathrm{E}-08$ & $4,12 E-08$ & 1.19E-04 & $1.80 \mathrm{E}-05$ & 4.29E-06 & $3,49 \mathrm{E}-05$ & $1.38 \mathrm{E}-09$ & $6.33 \mathrm{E}-06$ & $6.22 \mathrm{E}-05$ & $7.81 \mathrm{E}-08$ & $1.43 E+01$ \\
\hline 3 & $4.21 E-10$ & & & & $1.86 \mathrm{E}-09$ & & 4.49E-08 & 4.12E-08 & $1.19 \mathrm{E}-04$ & $1.80 \mathrm{E}-05$ & $4.29 \mathrm{E}-06$ & $3.49 \mathrm{E}-05$ & $1.38 \mathrm{E}-09$ & $6.33 \mathrm{E}-06$ & $6.22 \mathrm{E}-05$ & $7.81 E-08$ & $1.43 \mathrm{E}+01$ \\
\hline 4 & $1.18 \mathrm{E}-09$ & & & & $1.28 E-09$ & & $5.52 \mathrm{E}-08$ & $4,93 \mathrm{E}-08$ & $1.00 \mathrm{E}-05$ & $9.88 E-06$ & $2.21 E-06$ & $2.12 E-05$ & $4.54 \mathrm{E}-10$ & $2.89 \mathrm{E}-06$ & $1.85 E-04$ & $2.40 E-07$ & $1.71 E+01$ \\
\hline 5 & $9.27 \mathrm{E}-10$ & & & & 1.71E-09 & & $4.04 \mathrm{E}-08$ & $6.82 \mathrm{E}-08$ & $4.70 \mathrm{E}-05$ & $7.85 \mathrm{E}-06$ & $1.88 \mathrm{E}-06$ & $1.43 \mathrm{E}-05$ & 5.53E-10 & $2.79 \mathrm{E}-06$ & $1.50 \mathrm{E}-04$ & $1.91 \mathrm{E}-07$ & $3.51 E+00$ \\
\hline 6 & $1.26 \mathrm{E}-09$ & & & & $1.35 \mathrm{E}-09$ & & $5.05 E-08$ & $1,75 \mathrm{E}-08$ & & $5.17 E-06$ & $1.80 E-06$ & $2.29 \mathrm{E}-05$ & $3.53 E-09$ & $3.52 \mathrm{E}-06$ & $1.99 \mathrm{E}-04$ & $2.57 \mathrm{E}-07$ & 7.11E-02 \\
\hline 7 & $4.21 \mathrm{E}-10$ & & & & 1.86E-09 & & 4.49E-08 & 4.12E-08 & $1.19 \mathrm{E}-04$ & $1.80 \mathrm{E}-05$ & $4.29 \mathrm{E}-06$ & $3.49 \mathrm{E}-0.5$ & 1.38E-09 & $6.33 \mathrm{E}-06$ & $6.22 \mathrm{E}-05$ & $7.81 E-08$ & $5.72 E+00$ \\
\hline 8 & $5.46 E-10$ & & & & $1.26 \mathrm{E}-09$ & & $5.80 \mathrm{E}-08$ & $2.63 \mathrm{E}-08$ & $1.05 \mathrm{E}-04$ & 1.66E-05 & $3.90 \mathrm{E}-06$ & $4.21 \mathrm{E}-05$ & $4.91 E-09$ & $3.98 \mathrm{E}-06$ & $8.00 E-05$ & $1.03 E-07$ & $6.98 \mathrm{E}-01$ \\
\hline 9 & $1.52 \mathrm{E}-10$ & 1.11E-07 & $1.57 E-08$ & $1.62 E-09$ & 4.30E-10 & $1.62 E-09$ & $5.03 \mathrm{E}-09$ & $4.04 \mathrm{E}-08$ & $1.53 E-04$ & 4.00E-06 & $1.66 \mathrm{E}-06$ & $3.31 \mathrm{E}-05$ & 1.10E-09 & $6.12 \mathrm{E}-06$ & 4.53E-05 & 5.51E-08 & $1.40 \mathrm{E}+01$ \\
\hline 10 & $1.52 \mathrm{E}-10$ & 1.11E-07 & $1.57 E \cdot 08$ & $1.62 \mathrm{E}-09$ & $4.30 \mathrm{E}-10$ & $1.62 E-09$ & $5.03 \mathrm{E}-09$ & $4.04 E-08$ & $1.53 \mathrm{E}-04$ & $4.00 \mathrm{E}-06$ & $1.66 \mathrm{E}-06$ & $3.31 \mathrm{E}-05$ & 1.10E-09 & $6.12 \mathrm{E}-06$ & $4.53 E-05$ & $5.51 E-08$ & $2.45 E+00$ \\
\hline 11 & $2.07 E-13$ & 2.54E-09 & $2.09 \mathrm{E}-09$ & $3.23 E \cdot 10$ & $3.94 E-11$ & 3.23E-10 & $7.31 E-11$ & $1.38 \mathrm{E}-09$ & $1.91 \mathrm{E}-04$ & $1.85 \mathrm{E}-06$ & $1.16 \mathrm{E}-06$ & $7.57 \mathrm{E}-05$ & $2.48 \mathrm{E}-09$ & 7.43E-06 & $8.85 \mathrm{E}-06$ & & $2.54 E+00$ \\
\hline \multicolumn{18}{|c|}{ (1) } \\
\hline 13 & $1.52 E-10$ & 1.11E-07 & 1.57E-08 & 1.62E-09 & 4.30E-10 & $1.62 E-09$ & $5.03 E-09$ & $4,04 E-08$ & $1.53 \mathrm{E}-04$ & 4.00E-06 & $1.66 E-06$ & $3.31 E-0.5$ & $1.10 \mathrm{E}-09$ & $6.12 E-06$ & $4.53 E-05$ & $5.51 E-08$ & $2.54 \mathrm{E}+01$ \\
\hline 14 & $6.87 \mathrm{E}-10$ & $7.97 \mathrm{E}$ & $1.09 E-08$ & $9.41 E-10$ & $8.85 \mathrm{E}-10$ & $9.41 E-10$ & $1.69 E-08$ & 1.17E-07 & 5.34E-05 & & & $2.39 \mathrm{E}-05$ & & & & & $3.25 \mathrm{E}+01$ \\
\hline \multicolumn{18}{|c|}{ 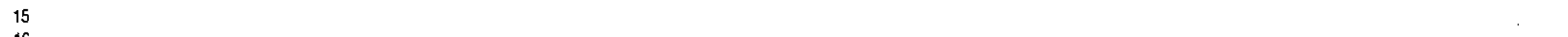 } \\
\hline \multirow{2}{*}{\multicolumn{18}{|c|}{$\begin{array}{l}16 \\
17\end{array}$}} \\
\hline & & & & & & & & & & & & & & & & & \\
\hline 18 & $9.64 E-11$ & & & & $7.32 \mathrm{E} \cdot 10$ & & $3.94 \mathrm{E}-08$ & & $1,68 \mathrm{E}-04$ & $2.40 E-05$ & $6.12 E-06$ & $1.12 \mathrm{E}-04$ & $7.85 \mathrm{E}-09$ & $1.21 E-05$ & & & $3.75 \mathrm{E}-02$ \\
\hline 19 & 5.39E-11 & & & & 3.55E-10 & & $3.25 \mathrm{E}-08$ & & $1.33 \mathrm{E}-04$ & $1.90 \mathrm{E}-05$ & $4.26 \mathrm{E}-06$ & $5.52 E-04$ & $8.75 \mathrm{E}-09$ & $5.34 E-05$ & & & $3.79 \mathrm{E}-02$ \\
\hline \multicolumn{18}{|c|}{ 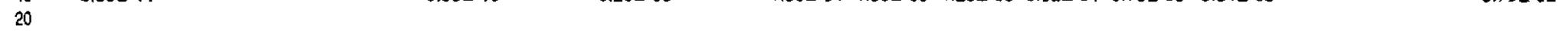 } \\
\hline 21 & & 3.63E-08 & $3.59 \mathrm{E}-08$ & 7.34E-09 & $4.94 \mathrm{E}-10$ & 7.34E-09 & $3.35 E-10$ & $2.21 E-08$ & $1.99 \mathrm{E}-04$ & $2.30 \mathrm{E}-07$ & $1.33 E-07$ & $4.95 E-06$ & $1.12 E-10$ & $5.71 E-07$ & $9.57 E-06$ & $E-08$ & $9.26 \mathrm{E}-03$ \\
\hline 22 & & $1.31 E-07$ & 4.7TE-08 & 7.76E-09 & $7.20 E-10$ & $7.76 E-09$ & $1.05 E-09$ & $2,86 \mathrm{E}-08$ & $1.98 E-04$ & & & & & & 1.15E-05 & $1.39 \mathrm{E}-08$ & $4.77 \mathrm{E}-03$ \\
\hline 23 & & & & & & & & & & & & & & & & & 2.68E-04 \\
\hline 24 & & & & & & & & & & & & & & & & & $2.91 \mathrm{E}-03$ \\
\hline 25 & $3.42 \mathrm{E}-09$ & & & & $7.78 E-09$ & & $7.10 \mathrm{E}-07$ & & 5.89E-03 & $8.41 E-04$ & $1.88 E-04$ & $4.65 \mathrm{E}-03$ & $3.87 E-08$ & $1.82 \mathrm{E}-04$ & & & $6.89 E+00$ \\
\hline 26 & 3.42E-09 & & & & $7.78 E-09$ & & $7.10 \mathrm{E}-07$ & & $5.89 E-03$ & $8.41 E-04$ & $E-04$ & $4.65 \mathrm{E}-03$ & $3.87 \mathrm{E}-08$ & $1.82 E-04$ & & & $8.24 E+00$ \\
\hline 27 & 3.42E.09 & & & & $7.78 E-09$ & & $7.10 \mathrm{E}-07$ & & 5.89E-03 & $8.41 E-04$ & $1.88 E-04$ & $4.65 \mathrm{E}-03$ & 3.87E-08 & $1.82 \mathrm{E}-04$ & & & $7.94 \mathrm{E}+00$ \\
\hline 28 & 3.42E-09 & & & & $7.78 E-09$ & & $E-07$ & & $=-03$ & $8.41 E-0.4$ & $E-04$ & $4.65 E-03$ & $3.87 E-08$ & $E=-04$ & & & $1 E+00$ \\
\hline 29 & $1.52 E-10$ & $1.11 E-07$ & $1.57 \mathrm{E}-08$ & $1.62 \mathrm{E}-09$ & $4.30 \mathrm{E}-10$ & $1.62 \mathrm{E}-09$ & $5.03 E-09$ & 4.04E-08 & $1.53 \mathrm{E}-04$ & $4.00 E-06$ & $1.66 \mathrm{E}-06$ & $3.31 E-0.5$ & 1.10E-09 & $6.12 \mathrm{E}-06$ & 4.53E-05 & 5.51E-08 & $9.93 \mathrm{E}+00$ \\
\hline 30 & $1.52 \mathrm{E}-10$ & $1.11 E-07$ & $1.57 \mathrm{E}-08$ & $1.62 \mathrm{E}-09$ & 4.30E-10 & 1.62E-09 & $5.03 \mathrm{E}-09$ & 4.04 & 1.53 & 4.00E-06 & $1.66 E-06$ & $3.31 E-05$ & $E-09$ & & & & $E+01$ \\
\hline 31 & $1.52 \mathrm{E}-10$ & $1.11 E-07$ & $1.57 E+08$ & 1.62E-09 & $4.30 \mathrm{E}-10$ & 1.62E-09 & 5.03E-09 & $4.04 \mathrm{E}-08$ & $1.53 \mathrm{E}-04$ & $4.00 E-06$ & 1.66E-06 & 3.31E-05 & 1.10E-09 & $6.12 \mathrm{E}-06$ & $4.53 \mathrm{E}-05$ & $5.51 E-08$ & $2.21 E+01$ \\
\hline 32 & & & 4.44E-08 & $9.97 \mathrm{E}-09$ & $6.36 \mathrm{E}-10$ & $9.97 E-09$ & $2.99 \mathrm{E}-10$ & $1.84 \mathrm{E}-08$ & $6.58 \mathrm{E}-03$ & $5.66 \mathrm{E}-05$ & $4.20 E-05$ & $3.27 E-03$ & $8.85 E-08$ & $2.28 \mathrm{E}-04$ & $1.91 E-04$ & $2.31 E-07$ & $1.89 E+01$ \\
\hline 33 & $2.89 E-08$ & $1.38 E-13$ & $1.15 E-09$ & $2.75 E-08$ & $6.19 E-08$ & $2.75 \mathrm{E}-08$ & $9.08 E-06$ & 3.53E-06 & $8.39 E-06$ & $2.54 E-03$ & 4.63E-04 & $1.45 \mathrm{E}-02$ & $2.37 E-08$ & $1.01 E-04$ & -03 & -06 & $E+\infty$ \\
\hline 34 & $4.59 \mathrm{E}-08$ & & & & 4.37E- 08 & & $3.09 \mathrm{E}-06$ & $2.38 \mathrm{E}-06$ & & $4.99 \mathrm{E}-04$ & 1.11E-04 & $2.62 \mathrm{E}-03$ & 2.31E-08 & $1.10 E-04$ & $6.37 E-03$ & 8.63E-06 & $7.72 E+00$ \\
\hline 35 & & & $4.33 E-08$ & $1.28 E-08$ & $7.53 E-10$ & $1.28 E-08$ & $4.45 E-10$ & $1.57 E-08$ & $6.63 E-03$ & $5.25 \mathrm{E}-05$ & $4.02 E-05$ & $3.54 \mathrm{E}-03$ & $9.02 E-08$ & $2.18 E-04$ & $1.60 \mathrm{E}-04$ & $1.96 \mathrm{E}-07$ & $1.51 E+01$ \\
\hline 36 & $1.52 \mathrm{E}-10$ & $1.11 \mathrm{E}-07$ & 1.57E-08 & $1.62 E-09$ & & & & & & & & $E-05$ & & & & & $E+01$ \\
\hline 37 & $1.52 E-10$ & $1.11 E-07$ & $1.57 \mathrm{E}-08$ & $1.62 \mathrm{E}-09$ & $4.30 \mathrm{E}-10$ & 1. $62 \mathrm{E}-09$ & 5.03E-09 & $4.04 E-08$ & $1.53 E-04$ & $4.00 \mathrm{E}-06$ & $1.66 \mathrm{E}-06$ & $3.31 E-05$ & $1.10 \mathrm{E}-09$ & $6.12 E-06$ & $4.53 \mathrm{E}-05$ & 5.51E-08 & $2.67 E+01$ \\
\hline 38 & & & 2.57E-07 & $3.92 \mathrm{E}-08$ & 2.59E-09 & 3.92E-08 & $3.64 \mathrm{E}-10$ & $2.24 \mathrm{E}-07$ & $7.00 \mathrm{E}-03$ & $2.18 E-05$ & $1.44 E-05$ & $1.13 \mathrm{E}-03$ & $2.71 \mathrm{E}-07$ & $2.40 \mathrm{E}-05$ & & $4.67 \mathrm{E}-08$ & t. $.89 \mathrm{E}+00$ \\
\hline 39 & & & $7.09 \mathrm{E}-08$ & $6.61 \mathrm{E}-09$ & $4.18 E-10$ & & & & & & & $E-03$ & & & & & $E+00$ \\
\hline 40 & $1.27 E-08$ & $3.47 E-07$ & $1.25 \mathrm{E}-07$ & $1.98 \mathrm{E}-08$ & $3.57 E-08$ & $1.98 E-08$ & $1.58 \mathrm{E}-06$ & $6.55 \mathrm{E}-07$ & 4.40E-03 & $5.61 \mathrm{E}-04$ & 1.37 E-04 & $1.61 \mathrm{E}-03$ & 1.67E-07 & $1.72 \mathrm{E}-04$ & $1.82 E-03$ & $2.35 \mathrm{E}-06$ & 2.91E-02 \\
\hline 41 & & & $2.57 \mathrm{E}-07$ & $3.92 \mathrm{E}-08$ & $2.59 E-09$ & 3.92E-08 & $3.64 \mathrm{E}-10$ & 2.24E-07 & $7.00 \mathrm{E}-03$ & 2.18E-05 & $1.44 E-05$ & $1.13 E-03$ & $2.71 E-07$ & $2.40 E-05$ & $3.77 \mathrm{E}-05$ & $4,67 \mathrm{E}-08$ & $3.05 E+00$ \\
\hline 42 & 4.39E-10 & $1.15 E-06$ & 4.22E-07 & $5.64 \mathrm{E}-08$ & $9.95 \mathrm{E}-09$ & $5.64 E-08$ & $1.75 \mathrm{E}-07$ & $3.47 \mathrm{E}-07$ & & & $7.01 E-05$ & $1.36 \mathrm{E}-03$ & 6.42 & $2.25 \mathrm{E}-04$ & & & $E+\infty$ \\
\hline 43 & & & 2.57E-.07 & $3.92 \mathrm{E}-08$ & $2.59 \mathrm{E}-09$ & $3.92 E-08$ & $3.64 \mathrm{E}-10$ & $2.24 \mathrm{E}-07$ & $7.00 \mathrm{E}-03$ & $2.48 \mathrm{E}-05$ & $1.44 \mathrm{E}-05$ & $1.13 \mathrm{E}-03$ & $2.71 E-07$ & $2.40 E-05$ & $3.77 E-05$ & $4.67 E-08$ & $1.49 E+00$ \\
\hline 44 & $3.42 \mathrm{E}-09$ & & & & $7.78 \varepsilon-09$ & & $7,10 \mathrm{E}-07$ & & $5.89 \mathrm{E}-03$ & $8.41 E-04$ & $1.88 \mathrm{E}-04$ & $4.65 E-03$ & 3.87E-08 & $1.82 \mathrm{E}-04$ & & & $1.03 E+01$ \\
\hline 45 & $3.42 \mathrm{E}-09$ & & & & $7.78 \mathrm{E}-09$ & & & & & & & 4.65E-03 & $3.87 E-08$ & & & & $9.76 \mathrm{E}+00$ \\
\hline 46 & 3.42E-09 & & & & $7.78 \mathrm{E}-09$ & & $7.10 \mathrm{E}-07$ & & $5.89 \mathrm{E}-03$ & 8.41E-04 & $1.88 E-04$ & $4.65 E-03$ & $3.87 E-08$ & $1.82 E-04$ & & & $9.90 E+00$ \\
\hline 47 & 3.42E-09 & & & & 7.78E-09 & & 7.10E-07 & & $5.89 E-03$ & $8.41 E-04$ & $1.88 \mathrm{E}-04$ & $4.65 E-03$ & $3.87 E-08$ & $1.82 E-04$ & & & $3.17 E+\infty 0$ \\
\hline 48 & & & & & & & & & & & & & & & & & $1.16 \mathrm{E}-01$ \\
\hline 49 & & & & & & & & & & & & & & & & & $2.02 E+01$ \\
\hline 50 & & & & & & & & & & & & & & & & & 4.07E-05 \\
\hline 51 & $1.89 E-10$ & 2.01E-06 & $1.34 \mathrm{E}-06$ & $3.40 E-08$ & $1.30 \mathrm{E}-08$ & $3.40 \mathrm{E}-08$ & $2,98 E-07$ & $5,95 E-07$ & 4.47E-03 & $1.99 \mathrm{E}-03$ & $8.20 \mathrm{E}-0$ & $1.12 \mathrm{E}-03$ & $1.72 \mathrm{E}-07$ & $6.54 \mathrm{E}-0$ & & & $9.54 \mathrm{E}-02$ \\
\hline
\end{tabular}

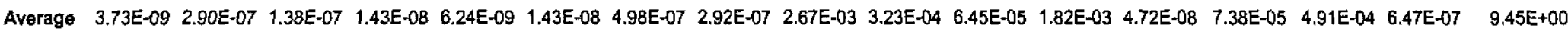




\section{Attachment 4}

Conversion of March 1999 Supernate Ci/gal Values for Decay to March 2003 
Attachmont 4

Converslon of March 1999 Supernate CUgal Values for Decay to March 2003

Supemate 1999 Report Conc. Values converted for decay to 3/2003

\begin{tabular}{|c|c|c|c|c|c|c|c|c|c|c|c|c|c|c|c|c|}
\hline Radionuclide & $\mathrm{H}-3$ & 0.14 & $00-60$ & $\mathrm{Ni}-59$ & Sr -90 & Y.90 & Tc-99 & $1-129$ & Am-243 & $\mathrm{Cm}-243$ & $\mathrm{Cm}-246$ & $\mathrm{Cm}-247$ & $\mathrm{Cm}-248$ & $C+249$ & Cf-25r & Cs 137 \\
\hline Half Life (years) & 12.33 & 5730 & 5.271 & 75000 & 28.5 & 28.5 & 213000 & 15700000 & 7370 & 28 & 4760 & 15400000 & 350000 & 352 & 900 & 30.17 \\
\hline \multicolumn{17}{|l|}{$\begin{array}{l}\text { WSAC-TR-9400290, Rev. 3 Table } 3 \\
\text { Supemate Values (CVigal) } \approx \text { Civgal at }\end{array}$} \\
\hline$t_{0=33+0003}$ & $2.00 \mathrm{E}-02$ & $9.50 E-06$ & $1.70 \mathrm{E}-01$ & $9.40 E-05$ & $4.70 E-03$ & $4.70 E-03$ & $9.00 E-04$ & $1.00 \mathrm{E}-06$ & $1.50 \mathrm{E}-09$ & $5.70 E-10$ & $1.40 E-13$ & $1.70 \mathrm{E} \cdot 19$ & $1.80 \mathrm{E} \cdot 19$ & $1.00 E-18$ & $2.00 E-20$ & 5 \\
\hline \multicolumn{17}{|l|}{ 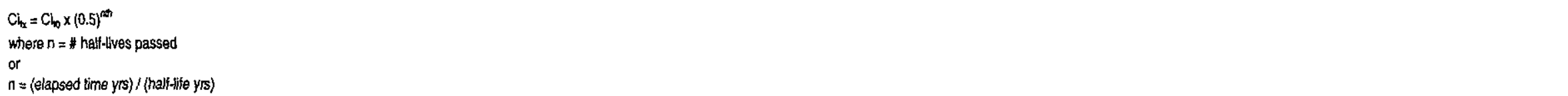 } \\
\hline $\begin{array}{l}t_{6}=3 / 1999 \\
t_{x}=3 / 2003 \\
\text { therefore, elapsed time }=4 \text { yrs }\end{array}$ & & & & & & & & & & & & & & & & \\
\hline $\mathrm{n}=$ elapsed time $4 \mathrm{yrs}) /$ (half-life yrs) & 0,324412 & 0.00069808 & 0.75886928 & $5.3333 E-05$ & 0.14035088 & 0.14035088 & $1.8779 E-05$ & $2.5478 E-07$ & 0.00054274 & 0.14285714 & 0.00084034 & $2.5974 E-07$ & $1.1429 E-05$ & $0.0 \div 136364$ & 0.00444444 & 0.13258204 \\
\hline 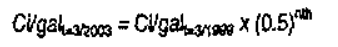 & $1.60 \mathrm{E}-02$ & $9.50 \mathrm{E}-06$ & $1.00 E-01$ & $9.40 E-05$ & $4.26 \mathrm{E}-03$ & $4.26 \mathrm{E}-03$ & $9.00 E-04$ & $1.00 E-06$ & $1.50 E-09$ & $5.16 \varepsilon-10$ & $1.40 E-13$ & $1.70 \mathrm{E}-19$ & $1.80 E-19$ & $9.92 E \cdot 19$ & $1.99 E-20$ & $4.56 \varepsilon+\infty 0$ \\
\hline
\end{tabular}




\section{Attachment 5}

\section{F- and H-Area Tank Farm Historic Supernate Data}




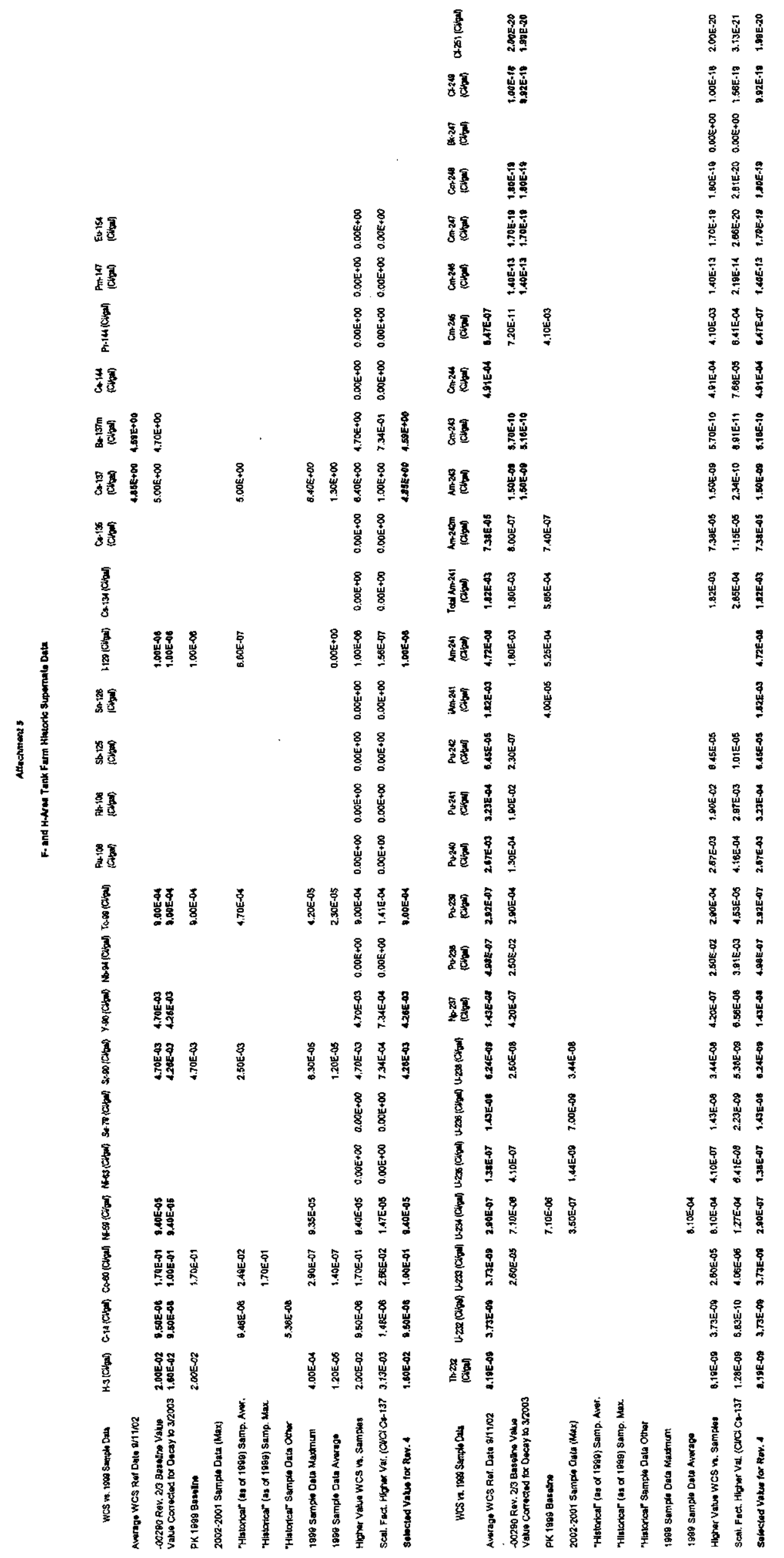


WSRC-TR-2000-00290

Revision 4

Attachment 6

Projected Americium/Curium Transfer from F-Canyon to H-Area Tank 51 


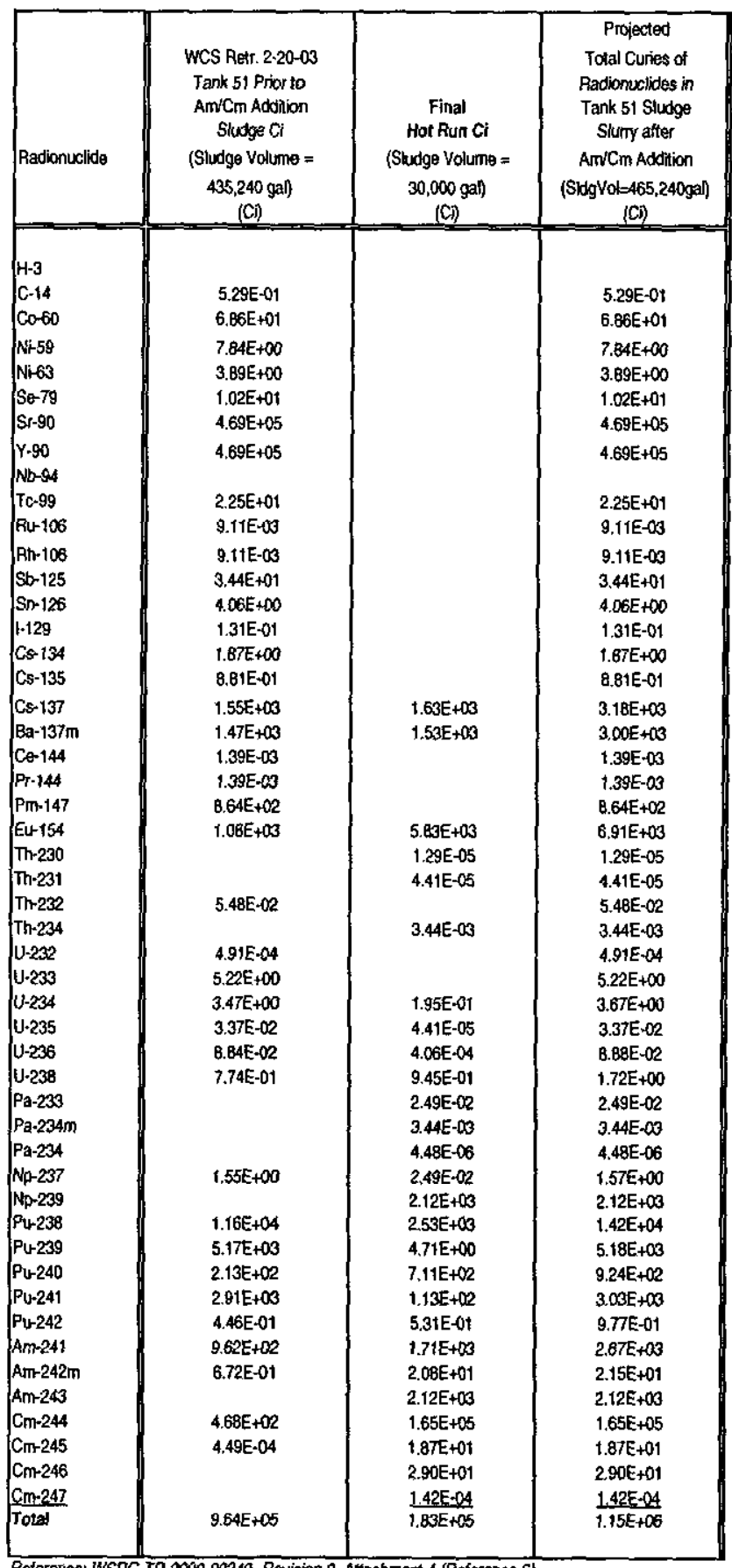




\section{Attachment 7}

F-Area Tank Farm Sludge Inventory from WCS 


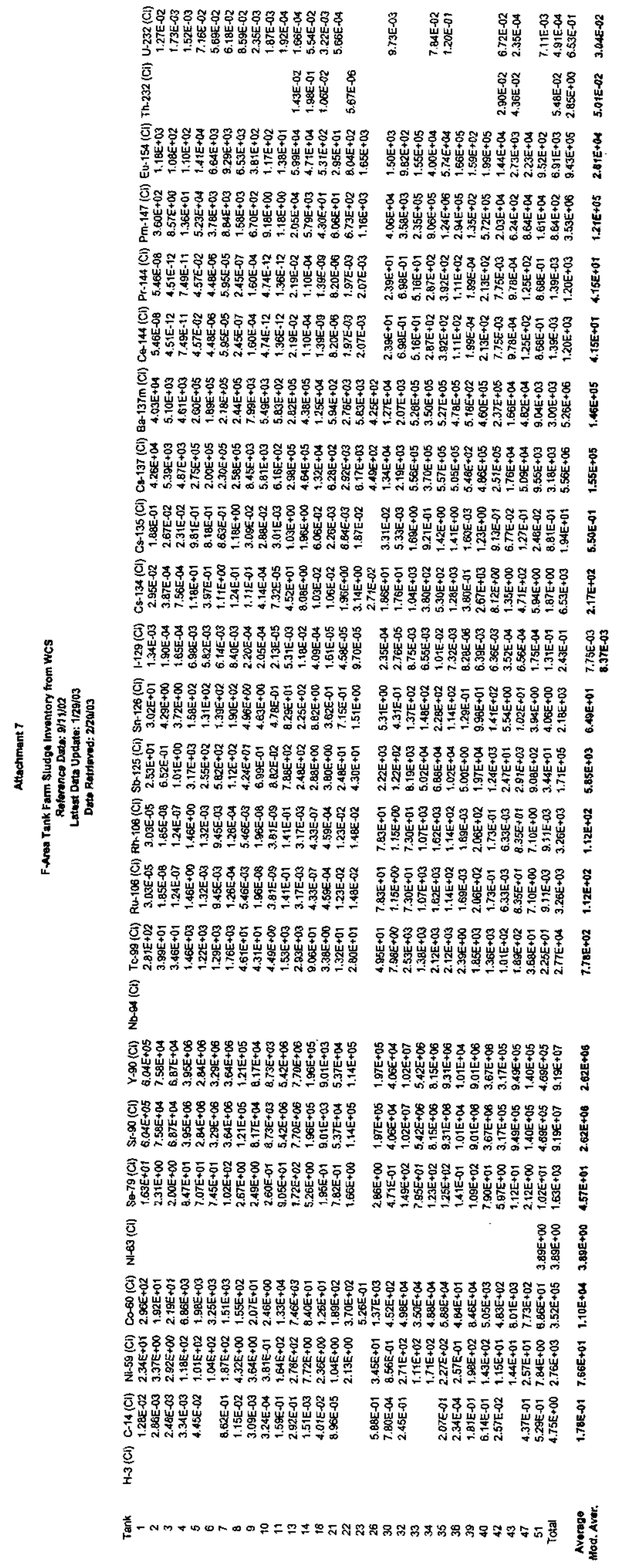




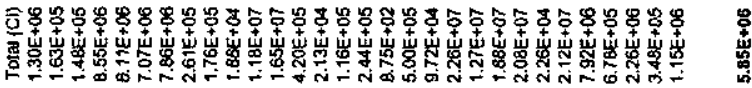

突

营

索䓝

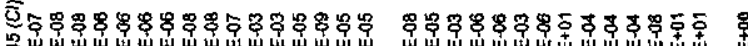

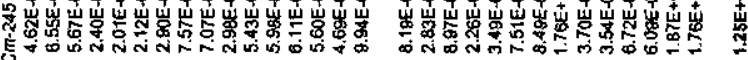

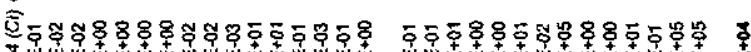

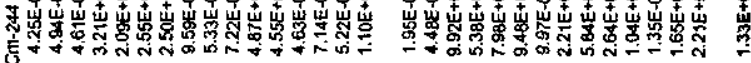
覀

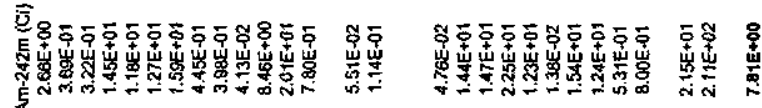
อิ

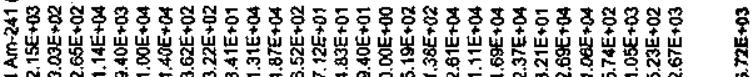

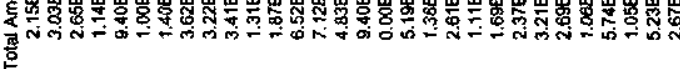

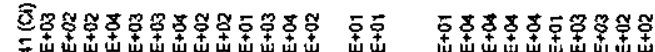

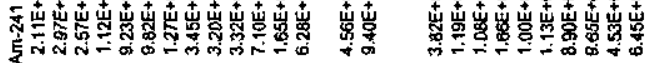

\section{$\widehat{\vec{Q}}$}

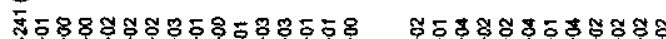

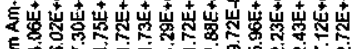

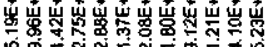

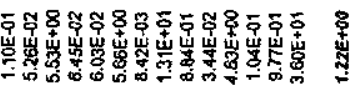

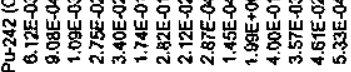

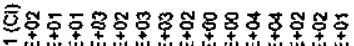

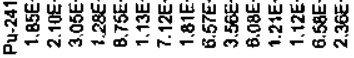

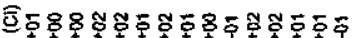

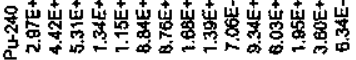

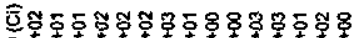

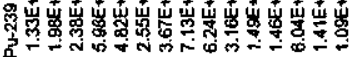

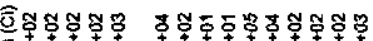

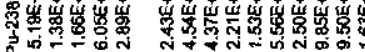

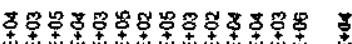

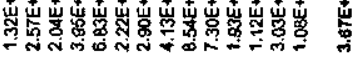

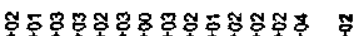

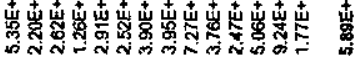

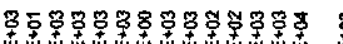

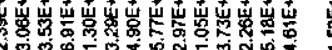

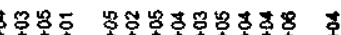

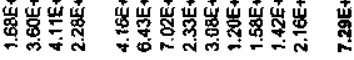

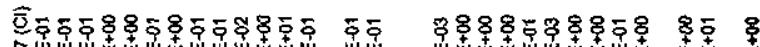

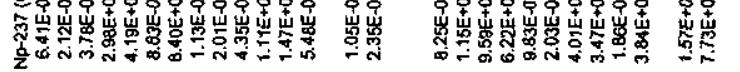

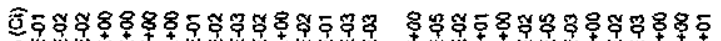

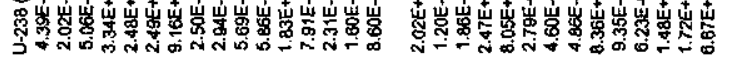

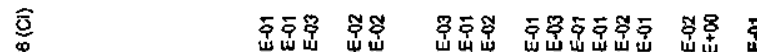

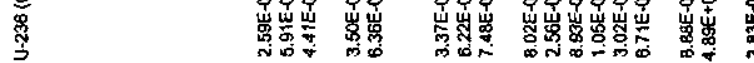

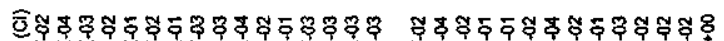

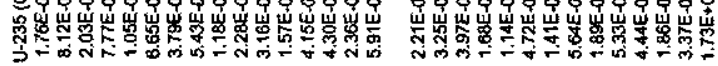

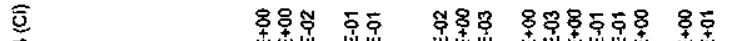

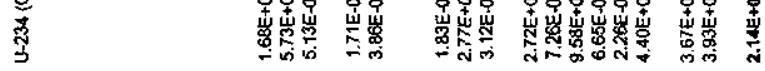

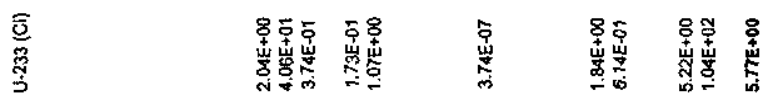

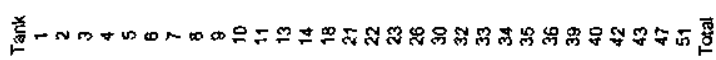


WSRC-TR-2000-00290

Revision 4

Attachment 8

Calculation of 95 Ci\% Supernate/5 Ci\% Sludge Scaling Factors 
Attachment 8

Calculation of $95 \mathrm{Ci} \%$ Supernate/5 Ci\% Sludge Scaling Factors

\begin{tabular}{|c|c|c|c|c|c|c|c|c|}
\hline & \multicolumn{2}{|c|}{ Sludge } & \multicolumn{2}{|c|}{ Supernate } & \multicolumn{4}{|c|}{95 Ci\% Supernate / 5 Ci\% Sludge Mixture } \\
\hline Isotope & $\mathbf{C i}$ & $\mathrm{Ci} \%$ & $\mathrm{Ci} / \mathrm{gal}$ & $\mathrm{Ci} \%$ & $\mathrm{Ci} \%$ & $\mathrm{Ci} / \mathrm{Ci}_{\mathrm{Cs}-137}$ & CiTRU/Ci Cs-137 & Ci/gal \\
\hline $\mathrm{H}-3$ & & & $1.60 \mathrm{E}-02$ & $1.67 \mathrm{E}-01$ & $1.59 \mathrm{E}-01$ & $3.28 E-03$ & & $1.59 \mathrm{E}-02$ \\
\hline $\mathbf{C}-14$ & 1.78E-01 & $3.04 \mathrm{E}-06$ & $9.50 \mathrm{E}-06$ & 9.92E-05 & $9.44 E-05$ & $1.96 \mathrm{E}-06$ & & $9.48 \mathrm{E}-06$ \\
\hline $\mathrm{Ni}-59$ & $7.66 \mathrm{E}+01$ & $1.31 E-03$ & $9.40 \mathrm{E}-05$ & $9.82 E-04$ & $9.98 \mathrm{E}-04$ & 2.07E-05 & & \\
\hline Co-60 & $1.10 E+04$ & 1.87E-01 & $1.00 E-01$ & $1.05 E+00$ & $1.01 \mathrm{E}+00$ & $2.08 \mathrm{E}-02$ & & $1.01 \mathrm{E}-01$ \\
\hline $\mathrm{Ni}-63$ & $3.89 \mathrm{E}+00$ & $6.66 \mathrm{E}-05$ & & & $3.33 \mathrm{E}-06$ & $6.89 \mathrm{E}-08$ & & \\
\hline $\mathrm{Sr}-90$ & $2.62 E+06$ & $4.49 E+01$ & $4.26 \mathrm{E}-03$ & $4.45 E-02$ & $2.29 E+00$ & $4.74 \mathrm{E}-02$ & & $2.30 \mathrm{E}-01$ \\
\hline$Y-90$ & $2.62 \mathrm{E}+06$ & $4.49 E+01$ & $4.26 \mathrm{E}-03$ & 4.45E-02 & $2.29 \mathrm{E}+00$ & $4.74 \mathrm{E}-02$ & & $2.30 \mathrm{E}-01$ \\
\hline Tc.99 & $7.78 \mathrm{E}+02$ & $1.33 E-02$ & $9.00 \mathrm{E}-04$ & $9.40 \mathrm{E}-03$ & $9.60 \mathrm{E}-03$ & $1.99 \mathrm{E}-04$ & & $9.64 \mathrm{E}-04$ \\
\hline-129 & $8.37 \mathrm{E}-03$ & $1,43 \mathrm{E}-07$ & $1.00 \mathrm{E}-06$ & $1.04 \mathrm{E}-05$ & $9.93 \mathrm{E}-06$ & $2.06 \mathrm{E}-07$ & & $9.98 \mathrm{E}-07$ \\
\hline Cs-137 & $1.55 \mathrm{E}+05$ & $2.65 \mathrm{E}+00$ & $4.85 \mathrm{E}+00$ & $5.07 E+01$ & $4.83 \mathrm{E}+01$ & $1.00 E+00$ & & $4.85 E+00$ \\
\hline $\mathrm{Ba}-137 \mathrm{~m}$ & $1.46 \mathrm{E}+05$ & $2.50 \mathrm{E}+00$ & $4.59 \mathrm{E}+00$ & $4.79 \mathrm{E}+01$ & $4.57 E+01$ & $9.46 \mathrm{E}-01$ & & $4.59 E+00$ \\
\hline $\mathrm{Pm}-147$ & $1.21 \mathrm{E}+05$ & $2.07 \mathrm{E}+00$ & & & $1.04 \mathrm{E}-01$ & $2.15 \mathrm{E}-03$ & & $1.04 \mathrm{E}-02$ \\
\hline Eu-154 & $2.81 \mathrm{E}+04$ & $4.81 \mathrm{E}-01$ & & & 2.41E-02 & $4.98 \mathrm{E}-04$ & & \\
\hline U-233 & $5.77 \bar{E}+00$ & $9.88 \mathrm{E}-05$ & $3.73 \mathrm{E}-09$ & $3.90 \mathrm{E}-08$ & 4.97E-06 & $1.03 E-07$ & & $5.00 \mathrm{E}-07$ \\
\hline $\mathrm{U}-234$ & $2.14 \mathrm{E}+00$ & $3.66 \mathrm{E}-05$ & $2.90 \mathrm{E}-07$ & 3.03E-06 & $4.71 E-06$ & $9.76 \mathrm{E}-08$ & & $4.73 \mathrm{E}-07$ \\
\hline $\mathrm{U}-235$ & $5.52 E-02$ & $9.44 \mathrm{E}-07$ & $1.38 \mathrm{E}-07$ & $1.44 \mathrm{E}-06$ & $1.42 \mathrm{E}-06$ & $2.94 \mathrm{E}-08$ & & $1.42 \mathrm{E}-07$ \\
\hline $\mathrm{U}-238$ & $2.31 \mathrm{E}+00$ & $3.95 \mathrm{E}-05$ & $6.24 \mathrm{E}-09$ & $6.52 \mathrm{E}-08$ & $2.04 \mathrm{E}-06$ & $4.22 E-08$ & & $2.05 \mathrm{E}-07$ \\
\hline $\mathrm{Np}-237$ & $2.53 E+00$ & $4.33 \mathrm{E}-05$ & $1.43 \mathrm{E}-08$ & $1.49 E-07$ & $2.31 \mathrm{E}-06$ & $4.78 E-08$ & $4.78 \mathrm{E}-08$ & $2.32 \mathrm{E}-07$ \\
\hline Np-239 & $2.12 \mathrm{E}+03$ & $3.63 E-02$ & & & $1.82 \mathrm{E}-03$ & $3.76 \mathrm{E}-05$ & & \\
\hline $\mathrm{Pu}-238$ & $7.29 E+04$ & $1.25 E+00$ & $4.98 \mathrm{E}-07$ & $5.20 E-06$ & $6.23 E-02$ & $1.29 \mathrm{E}-03$ & $1.29 \mathrm{E}-03$ & $6.26 \mathrm{E}-03$ \\
\hline $\mathrm{Pu}-239$ & $1.52 E+03$ & $2.60 \mathrm{E}-02$ & 2.92E-07 & $3.05 \mathrm{E}-06$ & $1.30 \mathrm{E}-03$ & $2.70 \mathrm{E}-05$ & $2.70 \mathrm{E}-05$ & $1.31 \mathrm{E}-04$ \\
\hline $\mathrm{Pu}-240$ & $5.89 \mathrm{E}+02$ & 1.01E-02 & $2.67 \mathrm{E}-03$ & $2.78 \mathrm{E}-02$ & $2.70 \mathrm{E}-02$ & $5.58 E-04$ & $5.58 \mathrm{E}-04$ & $2.71 \mathrm{E}-03$ \\
\hline Pu-241 & $3.67 E+04$ & $6.29 \mathrm{E}-01$ & $3.23 \mathrm{E}-04$ & $3.38 \mathrm{E}-03$ & $3.46 \mathrm{E}-02$ & $7.18 \mathrm{E}-04$ & & $3.48 E-03$ \\
\hline $\mathrm{Pu}-242$ & $1.22 \mathrm{E}+00$ & $2.09 \mathrm{E}-05$ & $6.45 \mathrm{E}-05$ & $6.73 \mathrm{E}-04$ & $6.41 \mathrm{E}-04$ & $1.33 \mathrm{E}-05$ & 1.33E-05 & $6.44 \mathrm{E}-05$ \\
\hline Am-241 & $6.72 \mathrm{E}+03$ & 1.15E-01 & 1.82E-03 & $1.91 \mathrm{E}-02$ & $2.39 \mathrm{E}-02$ & $4.94 \mathrm{E}-04$ & $4.94 \mathrm{E}-04$ & $2.40 \mathrm{E}-03$ \\
\hline Am-242m & $7.81 \mathrm{E}+00$ & 1.34E-04 & $7.38 \mathrm{E}-05$ & 7.71E-04 & $7.39 \mathrm{E}-04$ & $1.53 E-05$ & $1.53 \mathrm{E}-05$ & $7.42 \mathrm{E}-05$ \\
\hline $\mathrm{Am}-243$ & $2.12 \mathrm{E}+03$ & 3.63E-02 & 1.50E-09 & $1.57 \mathrm{E}-08$ & $1.82 \mathrm{E}-03$ & $3.76 E-05$ & $3.76 \mathrm{E}-05$ & $1.82 \mathrm{E}-04$ \\
\hline $\mathrm{Cm}-244$ & $1.33 \mathrm{E}+04$ & $2.28 \mathrm{E}-01$ & $4.91 \mathrm{E}-04$ & $5.13 \mathrm{E}-03$ & $1.63 \mathrm{E}-02$ & $3,37 E-04$ & & \\
\hline $\mathrm{Cm}-245$ & $1.25 E+00$ & $2.14 \mathrm{E}-05$ & $6.47 \mathrm{E}-07$ & $6.76 \mathrm{E}-06$ & $7.49 \mathrm{E}-06$ & $1.55 \mathrm{E}-07$ & 1.55E-07 & $7.52 \mathrm{E}-07$ \\
\hline $\mathrm{Cm}-246$ & $2.90 \mathrm{E}+01$ & $4.97 \mathrm{E}-04$ & $1.40 E-13$ & $1.46 \mathrm{E}-12$ & $2.48 \mathrm{E}-05$ & $5.15 \mathrm{E}-07$ & 5.15E-07 & $2.50 \mathrm{E}-06$ \\
\hline $\mathrm{Cm}-247$ & 1.42E-04 & $2.43 E-09$ & $1.70 \mathrm{E}-19$ & $1.78 \mathrm{E}-18$ & $1.21 \mathrm{E}-10$ & $2.51 \mathrm{E}-12$ & $2.51 \mathrm{E}-12$ & $1.22 \mathrm{E}-11$ \\
\hline Total & $5.84 E+06$ & $1.00 E+02$ & $9.57 \mathrm{E}+00$ & $1.00 \mathrm{E}+02$ & $1.00 \mathrm{E}+02$ & $2.07 \mathrm{E}+00$ & $2.44 \mathrm{E}-03$ & $1.00 E+01$ \\
\hline
\end{tabular}

WSRC-TR-94-00290

Revision 4 
F- and H-Area High Level Supernate Waste Stream Exclusion Criteria 


\section{F- and H-Area High Level Supernate Waste Stream Exclusion Criteria}

\begin{tabular}{|c|c|c|c|c|c|c|c|}
\hline \multirow[b]{2}{*}{ Isotope } & \multirow[b]{2}{*}{$\begin{array}{c}\text { Mean } \mathrm{Ci} / \mathrm{Ci} \\
\mathrm{C}_{5-137} \\
\end{array}$} & \multirow[b]{2}{*}{$\begin{array}{c}\text { Mean } \\
\text { Distribution (\%) }\end{array}$} & \multirow[b]{2}{*}{$\begin{array}{l}<1 \% \text { of } \\
\text { Dist?(a) }\end{array}$} & \multirow[b]{2}{*}{$\begin{array}{c}\text { Not } \\
\text { Expected }\end{array}$} & \multicolumn{3}{|c|}{ Distribution } \\
\hline & & & & & \begin{tabular}{|c|} 
RADs Remaining \\
after Exclusion \\
Criteria
\end{tabular} & $\begin{array}{c}\text { Mean } \\
\text { Distribution } \\
(\%) \\
\end{array}$ & \begin{tabular}{c}
\multicolumn{2}{c|}{ Re-normalized } \\
Distribution $\quad(\%)$ \\
\end{tabular} \\
\hline $\mathrm{H}-3$ & $3.28 \mathrm{E}-03$ & $1.59 \mathrm{E}-01$ & yes(b) & & $\mathrm{H}-3$ & $159 \mathrm{E}-01$ & \\
\hline$C-14$ & $1.96 \mathrm{E}-06$ & $9.44 E-05$ & & . & $C-14$ & $9.44 \mathrm{E}-05$ & $1.59 \mathrm{E}-01$ \\
\hline $\mathrm{Ni}-59$ & $2.07 \mathrm{E}-05$ & $9.98 \mathrm{E}-04$ & yes & & & $9.44 \mathrm{E}-0 \mathrm{D}$ & $9.44 \mathrm{E}-05$ \\
\hline $\mathrm{Co}-60$ & $2.08 \mathrm{E}-02$ & $1.01 \mathrm{E}+00$ & no & & $\mathrm{Co}-60$ & $1.01 \mathrm{E}+00$ & $3 \quad 1.01 \mathrm{E}+00$ \\
\hline $\mathrm{Ni}-63$ & $6.89 \mathrm{E}-08$ & $3.33 \mathrm{E}-06$ & yes & & & & \\
\hline Sr-90 & 4.74E- 02 & $2.29 \mathrm{E}+00$ & no & . & $\mathrm{Sr}-90^{\circ}$ & $2.29 \mathrm{E}+00$ & $229 \mathrm{E}+00$ \\
\hline $\mathrm{Y}-90$ & $4.74 \mathrm{E}-02$ & $2.29 \mathrm{E}+00$ & no & & $Y-90$ & $2.29 \mathrm{E}+00$ & $2.29 \mathrm{E}+00$ \\
\hline Te-99 & $1.99 \mathrm{E}-04$ & $9.60 \mathrm{E}-03$ & & .. & Te-99 & $9.60 \mathrm{E}-03$ & $9,60 \mathrm{E}-03 \quad \because$ \\
\hline I-129 & $2.06 \mathrm{E}-07$ & $9.93 \mathrm{E}-06$ & & & I-129 & $9.93 \mathrm{E}-06$ & $9.94 \mathrm{E}-06$ \\
\hline Cs-137 & $1.00 \mathrm{E}+00$ & $4.83 \mathrm{E}+01$ & no & & Cs-137 & $4.83 \mathrm{E}+01$ & $4.83 \mathrm{E}+0 \mathrm{I}^{3}$ \\
\hline$B a-137 m$ & $9.46 E-01$ & $4.57 E+01$ & no & & Ba- $137 \mathrm{~m}$ & $4.57 \mathrm{E}+01$ & $4.57 \mathrm{E}+01$ \\
\hline Pm-147 & $2.15 \mathrm{E}-03$ & $1.04 \mathrm{E}-01$ & yes(b) & & Pm-147. & $1.04 \mathrm{E}-01$ & $1.04 \mathrm{E}-01$ \\
\hline Eu-154 & $4.98 \mathrm{E}-04$ & $2.41 \mathrm{E}-02$ & yes & & & & \\
\hline U-233 & $1.03 \mathrm{E}-07$ & $4.97 \mathrm{E}-06$ & & & $U-2.33$ & $4.97 \mathrm{E}-06$ & $4.98 \mathrm{E}-06$ \\
\hline U-234 & $9.76 \mathrm{E}-08$ & 4.71E-06 & & & U-234 & $4.71 \mathrm{E}-06$ & $4.71 \mathrm{E}-06$ \\
\hline U-235 & $2.94 \mathrm{E}-08$ & $1.42 \mathrm{E}-06$ & & & U-235 & $\cdot 1.42 \mathrm{E}-06 \%$ & $1.42 \mathrm{E}-06$ \\
\hline U-238 & $4.22 \mathrm{E}-08$ & $2.04 \mathrm{E}-06$ & & & U-238 & $2.04 \mathrm{E}-06$ & $2.04 \mathrm{E}-06$ \\
\hline $\mathrm{Np}-237$ & $4.78 \mathrm{E}-08$ & $2.31 \mathrm{E}-06$ & & & $\mathrm{~Np}-237$ & 2.31E-06 & $2.31 \mathrm{E}-06$ \\
\hline Np-239 & $3.76 \mathrm{E}-05$ & $1.82 \mathrm{E}-03$ & yes & & & & \\
\hline Pu-238 & $1.29 \mathrm{E}-03$ & $6.23 \mathrm{E}-02$ & & & Pu-238 & $6.23 \mathrm{E}-02$ & $6.24 \mathrm{E}-02$ \\
\hline Pu-239 & $2.70 \mathrm{E}-05$ & $1.30 \mathrm{E}-03$ & & & Pu-239 & $1.30 \mathrm{E}-03$ & $1.30 \mathrm{E}-03$ \\
\hline Pu-240 & $5.58 \mathrm{E}-04$ & $2.70 \mathrm{E}-02$ & $\because$ & & $\mathrm{Pu}-240$ & $2.70 \mathrm{E}-02$ & $2.70 \mathrm{E}-02$ \\
\hline$P u-241$ & $7.18 \mathrm{E}-04$ & $3.46 \mathrm{E}-02$ & & & Pu-241 & $3.46 \mathrm{E}-02$ & $3.47 \mathrm{E}-02$ \\
\hline $\mathrm{Pu}-242$ & $1.33 \mathrm{E}-05$ & $\quad 6.41 \mathrm{E}-04$ & $\cdots$ & $\therefore$ & $\mathrm{Pu}-242$ & $6.41 \mathrm{E}-04$ & $6.41 \mathrm{E}-04$ \\
\hline Am-241 & $4.94 \mathrm{E}-04$ & $2.39 \mathrm{E}-02$ & & & Am-241 & $2.39 \mathrm{E}-02$ & $2.39 \mathrm{E}-02$ \\
\hline$A m-242 m$ & $1.53 \mathrm{E}-05$ & $7.39 \mathrm{E}-04$ & 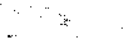 & i & $\mathrm{Am}-242 \mathrm{~m}$ & $7.39 \mathrm{E}-04$ & $7.39 \mathrm{E}-04$ \\
\hline $\mathrm{Am}-243$ & $3.76 \mathrm{E}-05$ & $1.82 \mathrm{E}-03$ & & & Am-243 & $1.82 \mathrm{E}-03$ & $1.82 \mathrm{E}-03$ \\
\hline $\mathrm{Cm}-244$ & $3.37 \mathrm{E}-04$ & $1.63 \mathrm{E}-02$ & yes & & $\because$ & & $\therefore$ \\
\hline $\mathrm{Cm}-245$ & $1.55 \mathrm{E}-07$ & $7.49 \mathrm{E}-06$ & & & $\mathrm{Cm}-245$ & $7.49 E-06$ & $7.49 \mathrm{E}-06$ \\
\hline $\mathrm{Cm}-246$ & $5.15 \mathrm{E}-07$ & $2.48 \mathrm{E} 05$ & & -4 & $\mathrm{Cm}-246$ & $2.48 \mathrm{E}-05$ & $2.49 \mathrm{E}-05$ \\
\hline $\mathrm{Cm}-247$ & $2.51 \mathrm{E}-12$ & $1.21 \mathrm{E}-10$ & & & $\mathrm{Cm}-247$ & $1.21 \mathrm{E}-10$ & $1.21 \mathrm{E}-10$ \\
\hline Total & $2.07 \mathrm{E}+00$ & $1: 00 \mathrm{E}+02$ & $x<$ & 3 & Total & $1.00 E+02$ & $\quad 100 \mathrm{E}+02$ \\
\hline
\end{tabular}

Bold = PA radionuclides

(a) for those radionuclides included because they were expected to be present at

(b) retained in distribution since they are close to $t \%$ of total activity

all fissile and transuranic isotopes retained in distribution 
F- and H-Area High Level Supernate Waste Stream Activity Distribution 
Attachment 10

F- and H-Area High Level Supernate Waste Stream Activity Distribution

\begin{tabular}{|c|c|c|}
\hline \multicolumn{3}{|c|}{$95 \%$ SUPERNATE $5 \%$ SLUDGE } \\
\hline Radionuclide & $\begin{array}{c}\text { Normalized } \\
\text { Distribution } \\
(\%) \\
\end{array}$ & $\begin{array}{c}\text { Scaling } \\
\text { Factors } \\
\text { Ci/Ci Cs-137 }\end{array}$ \\
\hline \multicolumn{3}{|c|}{ FHW-00001 } \\
\hline $\mathrm{H}-3$ & $1.59 \mathrm{E}-01$ & $3.28 E-03$ \\
\hline C-14 & 9.44E-05 & $1.96 \mathrm{E}-06$ \\
\hline Co-60 & $1.01 E+00$ & $2.08 \mathrm{E}-02$ \\
\hline Sr-90 & $2,29 E+00$ & $4.74 E-02$ \\
\hline$Y-90$ & $2.29 E+00$ & 4.74E-02 \\
\hline Tc-99 & $9.60 \mathrm{E}-03$ & $1.99 \mathrm{E}-04$ \\
\hline $1-129$ & $9.94 E-06$ & $2.06 \mathrm{E}-07$ \\
\hline Cs-137 & $4.83 E+01$ & $1.00 E+00$ \\
\hline $\mathrm{Ba}-137 \mathrm{~m}$ & $4.57 \mathrm{E}+01$ & $9.46 E-01$ \\
\hline Pm-147 & $1.04 \mathrm{E}-01$ & $2.15 \mathrm{E}-03$ \\
\hline U-233 & 4.98E-06 & $1.03 E-07$ \\
\hline$U-234$ & 4.71E-06 & $9.76 \mathrm{E}-08$ \\
\hline$U-235$ & 1.42E-06 & $2.94 \mathrm{E}-08$ \\
\hline$U-238$ & 2.04E-06 & $4.22 E-08$ \\
\hline $\mathrm{Np}-237$ & 2.31E-06 & $4.78 E-08$ \\
\hline Pu-238 & $6.24 E-02$ & $1.29 \mathrm{E}-03$ \\
\hline Pu-239 & 1.30E-03 & $2.70 \mathrm{E}-05$ \\
\hline Pu-240 & 2.70E-02 & $5.58 \mathrm{E}-04$ \\
\hline Pu-241 & $3.47 \mathrm{E}-02$ & $7.18 \mathrm{E}-04$ \\
\hline Pu-242 & 6.41E-04 & 1.33E-05 \\
\hline Am-241 & 2.39E-02 & $4.94 E-04$ \\
\hline$A m-242 m$ & 7.39E-04 & $1.53 E-05$ \\
\hline Am-243 & 1.82E-03 & $3.76 \mathrm{E}-05$ \\
\hline $\mathrm{Cm}-245$ & $7.49 \mathrm{E}-06$ & $1.55 \mathrm{E}-07$ \\
\hline $\mathrm{Cm}-246$ & 2.49E-05 & $5.15 E-07$ \\
\hline $\mathrm{Cm}-247$ & $1.21 \mathrm{E}-10$ & $2.51 E-12$ \\
\hline Total & $1.00 \mathrm{E}+02$ & $2.07 \mathrm{E}+00$ \\
\hline
\end{tabular}




\section{Attachment 11}

Comparison of F- and H-Area Supernate Waste Against WAC 3.17, Revision 7, Requirements 
Attachment 11

Comparison of F-and H-Area Supemate Waste Against WAC 3.17, Rev. 7, Requirements

Comparison Against WAC 3,17, Rev, 7, Requirements - Waste Stream FHW-00001

Comparison te Package Guidelines (Section 3.5.1)

$\begin{array}{ccc}\text { Isotope } & \begin{array}{c}\text { Average Ci/gal } \\ \text { Isotope }\end{array} & \begin{array}{c}\text { LAWV limit } \\ \text { ci/ft3 }\end{array} \\ \text { Hipernate/5 Ci\% Sludge' } & & \\ \text { C-14 } & 1.59 E-02 & 1.10 \mathrm{E}+01 \\ \text { TC-99 } & 9.48 \mathrm{E}-06 & 2.50 \mathrm{E}-05 \\ \mathrm{H}-129 & 9.64 \mathrm{E}-04 & 5.60 \mathrm{E}-05 \\ \mathrm{U}-234 & 9.98 \mathrm{E}-07 & 1.10 \mathrm{E}-08 \\ \text { U-238 } & 4.73 \mathrm{E}-07 & 1.10 \mathrm{E}-03 \\ & 2.05 \mathrm{E}-07 & 1.20 \mathrm{E}-03\end{array}$

\begin{tabular}{|c|c|c|c|c|c|}
\hline & Amt isotope in B-25 to reach & & & & \\
\hline $\begin{array}{ll}\text { LAWV lims } \\
\text { Cifor }\end{array}$ & LAWV Limit (gal) = LAWV limit & & & for $5000 \mathrm{lb}$ & min waste \\
\hline Ci for B-25 & in B-25/supernate activity & Total Curies in B-25 & TRU Curies & $\mathrm{nCi} / \mathrm{g}$ & $\begin{array}{l}\text { wh to not } \\
\text { be TRU }\end{array}$ \\
\hline $9.90 E+02$ & $6.22 E+04$ & & & & \\
\hline $2.25 E-03$ & $2.37 \mathrm{E}+02$ & & & & \\
\hline $5.04 E-03$ & $5.23 E+00$ & & & & \\
\hline $9.90 E-07$ & 9.92E-01 & $9.96 \mathrm{E}+00$ & 1.17E-02 & 5.168241 & 258,412 \\
\hline $9.90 E-02$ & $2.09 E+05$ & & & & \\
\hline $1.08 \mathrm{E}-01$ & $5.28 E+05$ & & & & \\
\hline
\end{tabular}

Sum of Eractions Calculation (Section 3.5.2)

isotope

Average Ci/gal

Isotope $95 \mathrm{Ci} \%$ Supernate/5 Ci\% Sludge' Cift3 supernate

$1.19 E-01$

$1.59 \mathrm{E}-02$

9.48E-06

$9.64 \mathrm{E}-04$

$9.98 \mathrm{E}-07$

4.73E- 07

7.09E-05

7.21E-03

7.46E- 06

$3.54 E-06$

2.05E-07

$1.53 \mathrm{E}-06$

A3 supernate/fl3 waste

At3 supernate/B-25

$1.23 E-03$

1.11E-01

Gal supernate/B-25

8.30E-01

Equivalent Curies

8.33E+00

Total Activity, blended 95 Ci\% Supernate/5 Ci\% Sludge"

$1.00 \mathrm{E}+01 \mathrm{Ci} / \mathrm{gal}$

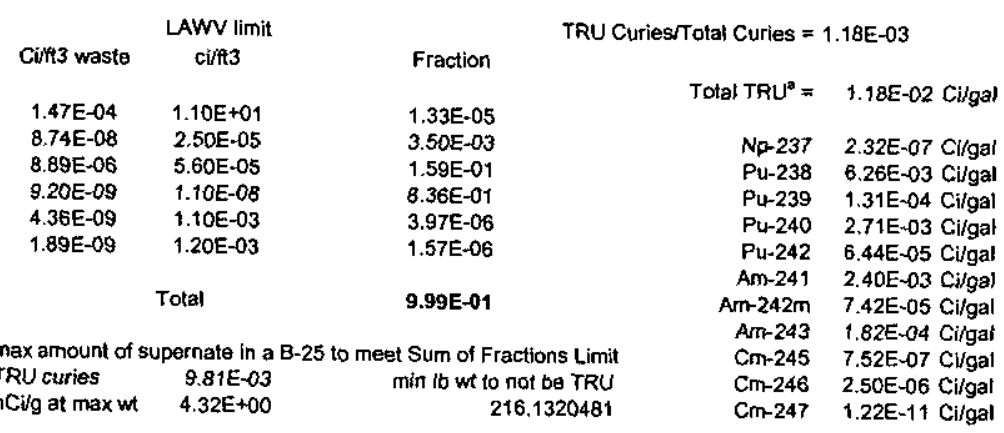

Nuclear Criticality Safety Criteria (Section 3.5.3)

$$
\begin{gathered}
\text { Isotope } \\
\text { Average Ci/gal }
\end{gathered}
$$

$95 \mathrm{Ci} \%$ Supernatel5 $\mathrm{Ci} \%$ Sludge'

5.00E-07

1.42E-07

1.31E-04

3.48E-03

7.42E-05

7.52E-07

1.22E-11

Gal Supernate

Equiv Curies
Specific Activity

Cilg

9.648E-03

2.160E-06

$6.132 \mathrm{E} \cdot 02$

$1.034 E+02$

$9.717 \mathrm{E}+\mathrm{OO}$

1.716E-01

9.396E-05

712.7

7.16E+03

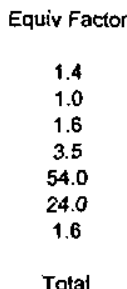

FGE

$5.17 E-02$

4.70E+0

$2.43 E+00$

3.39E-02

$2.94 \mathrm{E}-01$

7.50E-02

$1,48 E-04$

4.99E+01

From Attachment 6 
WSRC-TR-2000-00290

Revision 4

\section{Attachment 12}

Comparison of Burial Ground Parameters for $100 \%$ Supernate and 95/5 Ci\% Supernate/Sludge Mixture 
SRS-DTC 3.10 - Summary Output

Case Title: Att 12 (Pg 1 of 3) Case 1: Assume 100\% Supernate File Name: C:ISRSDTCICASE1.MS1

Run Date: 3/11/2003 11:13:19 AM Total Run Time:5 seconds

Run By:
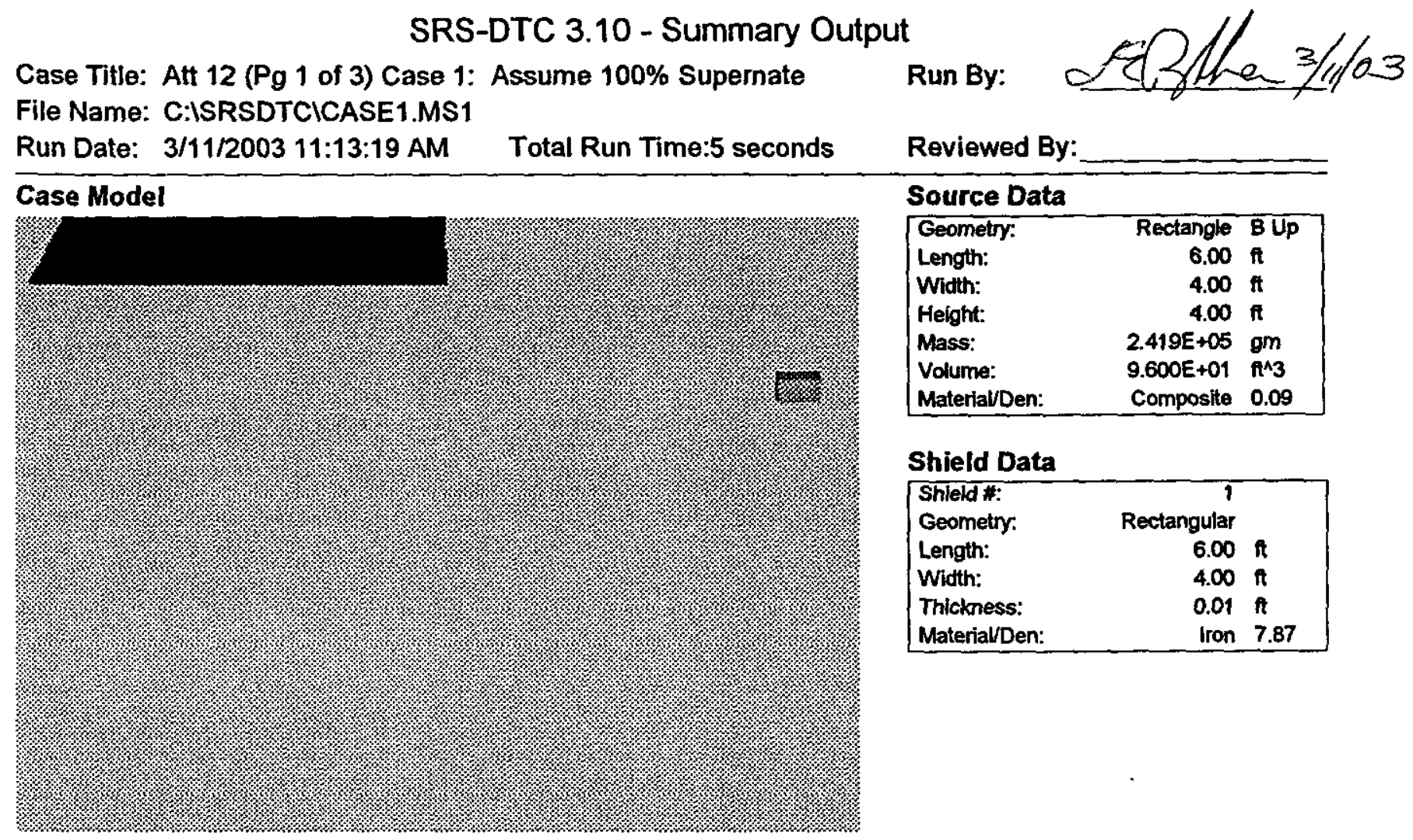

Reviewed By:

Source Data

\begin{tabular}{lrl|}
\hline Geometry: & Rectangle $\mathrm{B}$ Up \\
Length: & $6.00 \mathrm{ft}$ \\
Width: & $4.00 \mathrm{ft}$ \\
Height: & $4.00 \mathrm{ft}$ \\
Mass: & $2.419 E+05 \mathrm{gm}^{\mathrm{m}}$ \\
Volume: & $9.600 E+01 \mathrm{f}^{\wedge} 3$ \\
MateriaVDen: & Composite & 0.09 \\
\hline
\end{tabular}

\section{Shield Data}

\begin{tabular}{|lr|}
\hline Shield \#: & 1 \\
Geometry: & Rectangular \\
Length: & $6.00 \mathrm{ft}$ \\
Width: & $4.00 \mathrm{ft}$ \\
Thickness: & $0.01 \mathrm{ft}$ \\
MaterialDen: & Iron 7.87 \\
\hline
\end{tabular}

Integration Parameters: Length: 10 Width: 10 Height: 10

\section{Source Activity - Std. Grouping - Lower Energy Cutoff $=0.000 E+00$}

\begin{tabular}{|lcc|llc|}
\hline Nuclide & Curies & Bq & Nuclide & Curies & Bq \\
\hline Am-241 & $3.760 E-04$ & $1.391 E+07$ & $1-129$ & $2.060 E-07$ & $7.622 E+03$ \\
Am-242m & $1.520 E-05$ & $5.624 E+05$ & Ni-59 & $1.940 E-05$ & $7.178 E+05$ \\
Am-243 & $3.090 E-10$ & $1.143 E+01$ & Np-237 & $6.010 E-08$ & $2.224 E+03$ \\
Ba-137m & $9.460 E-01$ & $3.500 E+10$ & $P u-236$ & $1.030 E-07$ & $3.811 E+03$ \\
C-14 & $1.960 E-06$ & $7.252 E+04$ & Pu-239 & $6.030 E-08$ & $2.231 E+03$ \\
Cm-244 & $1.010 E-04$ & $3.737 E+06$ & $P u-240$ & $5.490 E-04$ & $2.031 E+07$ \\
Cm-245 & $1.330 E-07$ & $4.921 E+03$ & Pu-241 & $6.670 E-05$ & $2.468 E+06$ \\
Cm-246 & $2.880 E-14$ & $1.066 E-03$ & Pu-242 & $1.330 E-05$ & $4.921 E+05$ \\
Cm-247 & $3.500 E-20$ & $1.295 E-09$ & Sr-90 & $8.790 E-04$ & $3.252 E+07$ \\
Co-60 & $2.070 E-02$ & $7.659 E+08$ & TC-99 & $1.860 E-04$ & $6.882 E+06$ \\
Cs-137 & $1.000 E+00$ & $3.700 E+10$ & U-233 & $7.690 E-10$ & $2.845 E+01$ \\
H-3 & $3.290 E-03$ & $1.217 E+08$ & U-234 & $5.980 E-08$ & $2.213 E+03$ \\
\hline
\end{tabular}

\section{Case Results}

\begin{tabular}{|c|c|c|c|c|c|c|c|}
\hline \multirow{3}{*}{ Detector \# } & \multicolumn{3}{|c|}{$\begin{array}{c}\text { Detector Coordinates } \\
\text { in } \mathrm{ft}\end{array}$} & \multicolumn{3}{c|}{$\begin{array}{c}\text { Exposure Rates in Air } \\
\mathrm{mR} / \mathrm{hr}\end{array}$} & \multicolumn{2}{c|}{$\begin{array}{c}\text { Dose Equivalent Rate } \\
\mathrm{mRem} / \mathrm{hr}\end{array}$} \\
\cline { 2 - 7 } & $\mathrm{X}$ & $\mathrm{\gamma}$ & $\mathrm{Z}$ & w/o BuildUp & with BuildUp & w/o BuildUp & with BuildUp \\
\hline 1 & 8.01 & 2.00 & 0.00 & $3.345 E+01$ & $5.551 \mathrm{E}+01$ & $3.085 \mathrm{E}+01$ & $5.119 \mathrm{E}+01$ \\
\hline
\end{tabular}


SRS-DTC 3.10 - Summary Output

Case Title: Att 12 (Pg 2 of 3) Case 2: 95/5 Ci\% Supernate/Sludge

File Name: C:ISRSDTCICASE2.MS1

Run Date: 3/11/2003 11:22:05 AM

Case Model

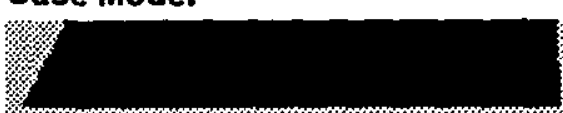

Total Run Time:5 seconds

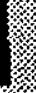

Run By:

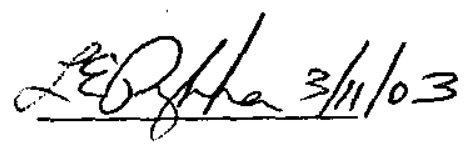

Reviewed By:

\section{Source Data}

\begin{tabular}{|lrl|}
\hline Geometry: & Rectangle & $\mathrm{B} \mathrm{Up}$ \\
Length: & $6.00 \mathrm{ft}$ \\
Width: & $4.00 \mathrm{ft}$ \\
Helght: & $4.00 \mathrm{ft}$ \\
Mass: & $2.419 E+05 \mathrm{gm}$ \\
Volume: & $9.600 E+01$ & $\mathrm{~A}^{\wedge} 3$ \\
MaterialDen: & Composite & 0.09 \\
\hline
\end{tabular}

\section{Shield Data}

\begin{tabular}{|lr|}
\hline Shield F: & 1 \\
Geometry: & Rectangular \\
Length: & $6.00 \mathrm{ft}$ \\
Width: & $4.00 \mathrm{ft}$ \\
Thickness: & $0.01 \mathrm{ft}$ \\
Material/Oen: & iron 7.87 \\
\hline
\end{tabular}

Integration Parameters: Length: 10 Width: 10 Height: 10

Source Activity - Std. Grouping - Lower Energy Cutoff $=0.000 E+00$

\begin{tabular}{|lcc|llc|}
\hline Nuclide & Curies & Bq & Nuclide & Curies & Bq \\
\hline Am-241 & $4.940 E-04$ & $1.828 E+07$ & H-3 & $3.280 E-03$ & $1.214 \mathrm{E}+08$ \\
Am-242m & $1.530 \mathrm{E}-05$ & $5.661 \mathrm{E}+05$ & $\mathrm{l}-129$ & $2.060 \mathrm{E}-07$ & $7.622 \mathrm{E}+03$ \\
Am-243 & $3.760 \mathrm{E}-05$ & $1.391 \mathrm{E}+06$ & $\mathrm{Ni}-59$ & $2.070 \mathrm{E}-05$ & $7.659 \mathrm{E}+05$ \\
$\mathrm{Ba}-137 \mathrm{~m}$ & $9.460 \mathrm{E}-01$ & $3.500 \mathrm{E}+10$ & $\mathrm{Ni}-63$ & $6.890 \mathrm{E}-08$ & $2.549 \mathrm{E}+03$ \\
$\mathrm{C}-14$ & $1.960 \mathrm{E}-06$ & $7.252 \mathrm{E}+04$ & $\mathrm{~Np}-237$ & $4.780 \mathrm{E}-08$ & $1.769 \mathrm{E}+03$ \\
$\mathrm{Cm}-244$ & $3.370 \mathrm{E}-04$ & $1.247 \mathrm{E}+07$ & $\mathrm{~Np}-239$ & $3.760 \mathrm{E}-08$ & $1.391 \mathrm{E}+03$ \\
$\mathrm{Cm}-245$ & $1.550 \mathrm{E}-07$ & $5.735 \mathrm{E}+03$ & Pm-147 & $2.150 \mathrm{E}-03$ & $7.955 \mathrm{E}+07$ \\
$\mathrm{Cm}-246$ & $5.150 \mathrm{E}-07$ & $1.906 \mathrm{E}+04$ & Pu-238 & $1.290 \mathrm{E}-03$ & $4.773 \mathrm{E}+07$ \\
$\mathrm{Cm}-247$ & $2.150 \mathrm{E}-12$ & $7.955 \mathrm{E}-02$ & $\mathrm{Pu}-239$ & $2.700 \mathrm{E}-05$ & $9.990 \mathrm{E}+05$ \\
$\mathrm{C}-60$ & $2.080 \mathrm{E}-02$ & $7.696 \mathrm{E}+08$ & Pu-240 & $5.580 \mathrm{E}-04$ & $2.065 \mathrm{E}+07$ \\
$\mathrm{Cs}-137$ & $1.000 \mathrm{E}+00$ & $3.700 \mathrm{E}+10$ & Pu-241 & $7.180 \mathrm{E}-04$ & $2.657 \mathrm{E}+07$ \\
$\mathrm{Eu}-154$ & $4.980 \mathrm{E}-04$ & $1.843 \mathrm{E}+07$ & Pu-242 & $1.330 \mathrm{E}-05$ & $4.921 \mathrm{E}+05$ \\
\hline
\end{tabular}

\section{Case Results}

\begin{tabular}{|c|c|c|c|c|c|c|c|}
\hline \multirow[b]{2}{*}{ Detector \# } & \multicolumn{3}{|c|}{$\begin{array}{l}\text { Detector Coordinates } \\
\text { in } \mathrm{ft}\end{array}$} & \multicolumn{2}{|c|}{$\begin{array}{c}\text { Exposure Rates in Air } \\
\mathrm{mR} / \mathrm{hr}\end{array}$} & \multicolumn{2}{|c|}{$\begin{array}{c}\text { Dose Equivalent Rate } \\
\text { mRem } / \mathrm{hr}\end{array}$} \\
\hline & $x$ & $\bar{Y}$ & $\mathbf{Z}$ & w/o BuildUp & with BuildUp & w/o BuildUp & with BuildUR \\
\hline 1 & 8.01 & 2.00 & 0.00 & $3.351 E+01$ & $5.559 \bar{E}+01$ & $3.090 E+01$ & 5.126E+01 \\
\hline
\end{tabular}


Both Cases:

500 Lb B-25

Job Control Waste

Case 1

Basis: 1 Ci Cs-137

$51.19 \mathrm{mrem} / \mathrm{hr}$

(See Pg 1 of 3 DTC Run)
Basis: $1 \mathrm{mrem} / \mathrm{hr}$

1.954E-02 Ci Cs-137

2.171E-04 Cl Cs-137/ft3
Case 2

Basis: $1 \mathrm{Ci} \mathrm{Cs}-137$

$51.26 \mathrm{mrem} / \mathrm{hr}$

(See Pg 2 of 3 DTC Run)
Basis: $1 \mathrm{mrem} / \mathrm{hr}$

1.951E-02 Ci Cs-137

2.168E-04 Ci Cs-137/ft3

\begin{tabular}{|c|c|c|c|c|c|c|c|c|c|c|}
\hline & \multicolumn{5}{|c|}{$100 \%$ Supernate } & \multicolumn{5}{|c|}{$95 \mathrm{Ci} \%$ Supernate $/ 5 \mathrm{Ci} \%$ Sludge Mixture } \\
\hline Isotope & $\mathrm{Ci} \%$ & Ci/Ci Cs-137 & Cifft3 & EFr'ns & nCilg TRU & $\mathrm{Ci} \%$ & $\mathrm{Ci} / \mathrm{Ci} \mathrm{Cs}=137$ & $\mathrm{Ci} / \mathrm{ft} 3$ & EFr'ns & nCilg TRU \\
\hline $\mathrm{H}-3$ & 1.67E-01 & $3.29 \mathrm{E}-03$ & $7.15 \mathrm{E}-07$ & & & $1.59 \mathrm{E}-01$ & $3.28 \mathrm{E}-03$ & $7.12 \mathrm{E}-07$ & & \\
\hline$C-14$ & $9.92 \mathrm{E}-05$ & $1.96 \mathrm{E}-06$ & $4.25 \mathrm{E}-10$ & $1.70 \mathrm{E}-05$ & & $9.44 E-05$ & $1.96 \mathrm{E}-06$ & $4.24 \mathrm{E}-10$ & $1 . \overline{70 E}-05$ & \\
\hline Ni-59 & $9.82 E-04$ & $1.94 \mathrm{E}-05$ & 4.21E-09 & & & $9.98 \mathrm{E}-04$ & $2.07 \mathrm{E}-05$ & $4.48 \mathrm{E}-09$ & & \\
\hline Co-60 & $1.05 E+00$ & $2.07 E-02$ & 4.49E-06 & & & $1.01 \mathrm{E}+00$ & $2.08 \mathrm{E}-02$ & $4.52 \mathrm{E}-06$ & & \\
\hline $\mathrm{Ni}-63$ & & & & & & $3.33 \mathrm{E}-06$ & $6.89 E-08$ & $1.49 \mathrm{E}-11$ & & \\
\hline Sr-90 & $4.45 \mathrm{E}-02$ & $8.79 E-04$ & $1.91 E-07$ & & & $2.29 \mathrm{E}+00$ & $4.74 \mathrm{E}-02$ & $1.03 \mathrm{E}-05$ & & \\
\hline$Y-90$ & $4.45 \mathrm{E}-02$ & $8.79 E-04$ & $1.91 \mathrm{E}=07$ & & & $2.29 \mathrm{E}+00$ & $4.74 \mathrm{E}-02$ & $1.03 \mathrm{E}-05$ & & \\
\hline TC-99 & $9.40 \mathrm{E}-03$ & $1.86 E-04$ & $4.03 \mathrm{E}-08$ & $7.19 \bar{E}-04$ & & $9.60 E-03$ & $1.99 E-04$ & 4.31E-08 & $7.69 E-04$ & \\
\hline $1-129$ & $1.04 \mathrm{E}-05$ & $2.06 \mathrm{E}-07$ & $4.47 \mathrm{E}-11$ & 4.07E-03 & & $9.93 E-06$ & $2.06 \mathrm{E}-07$ & $4.46 \mathrm{E}-11$ & $4.05 \mathrm{E}-03$ & \\
\hline Cs-137 & $5.07 E+01$ & $1.00 \mathrm{E}+00$ & $2.17 \mathrm{E}-04$ & & & $4.83 \mathrm{E}+01$ & $1.00 \mathrm{E}+00$ & $2.17 \mathrm{E}-04$ & & \\
\hline $\mathrm{Ba}-137 \mathrm{~m}$ & $4.79 \mathrm{E}+01$ & $9.46 \mathrm{E}-01$ & 2.05E-04 & & & $4.57 \bar{E}+01$ & 9.46E-01 & $2.05 \mathrm{E}-04$ & & \\
\hline $\mathrm{Pm}-147$ & & & & & & 1.04E-01 & $2.15 \mathrm{E}-03$ & $4.66 \mathrm{E}-07$ & & \\
\hline EU-154 & & & & & & $2.41 \mathrm{E}-02$ & $4.98 \mathrm{E}-04$ & $1.08 \mathrm{E}-07$ & & \\
\hline $\mathrm{U}-233$ & $3.90 \mathrm{E}-08$ & $7.69 \mathrm{E}-10$ & $1.67 \mathrm{E}-13$ & & & 4.97E-06 & $1.03 \mathrm{E}-07$ & $2.23 \mathrm{E}-11$ & & \\
\hline U-234 & $3.03 \mathrm{E}-06$ & $5.98 \mathrm{E}-08$ & $1.30 \mathrm{E}-11$ & $1.18 \mathrm{E}-08$ & & $4.71 \mathrm{E}-06$ & $9.76 \mathrm{E}-08$ & $2.12 \mathrm{E}-11$ & $1.92 E-08$ & \\
\hline U-235 & $1.44 \mathrm{E}-06$ & $2.85 \mathrm{E}-08$ & $6.18 \mathrm{E}-12$ & & & 1.42E-06 & $2.94 \mathrm{E}-08$ & $6.36 E-12$ & & \\
\hline U.238 & $6.52 E-08$ & $1.29 \mathrm{E}-09$ & $2.79 \mathrm{E}-13$ & $2.33 \mathrm{E}-10$ & & $2.04 \mathrm{E}-06$ & $4.22 \mathrm{E}-08$ & $9.14 \mathrm{E}-12$ & $7.62 \mathrm{E}-09$ & \\
\hline $\mathrm{Np}-237$ & $1.49 \mathrm{E}-07$ & $2.94 \mathrm{E}-09$ & $6.39 \mathrm{E}-13$ & & $2.53 \mathrm{E}-07$ & $2.31 \mathrm{E}-06$ & $4.78 \mathrm{E}-08$ & $1.04 \mathrm{E}-11$ & & $4.11 \mathrm{E}-06$ \\
\hline $\mathrm{Np}-239$ & & & & & & $1.82 E-03$ & $3.76 \mathrm{E}-05$ & $8.16 \mathrm{E}-09$ & & \\
\hline $\mathrm{Pu}-238$ & $5.20 \mathrm{E}-06$ & $1.03 \mathrm{E}-07$ & $2.23 \mathrm{E}-11$ & & $8.84 \mathrm{E}-06$ & $6.23 \mathrm{E}-02$ & $1.29 \mathrm{E}-03$ & 2.80 E- 07 & & $1.11 \mathrm{E}-01$ \\
\hline PU-239 & $3.05 \mathrm{E}-06$ & $6.03 \mathrm{E}-08$ & $1.31 \mathrm{E}-11$ & & $5.19 \mathrm{E}-06$ & $1.30 \mathrm{E}-03$ & $2.70 \mathrm{E}-05$ & $5.85 \mathrm{E}-09$ & & $2.32 E-03$ \\
\hline $\mathrm{Pu}-240$ & $2.78 \mathrm{E}-02$ & $5.49 \mathrm{E}-04$ & $1.19 \mathrm{E}-07$ & & $4.73 \mathrm{E}-02$ & $2.70 \mathrm{E}-02$ & $5.58 \mathrm{E}-04$ & $1.21 \mathrm{E}-07$ & & $4.80 \mathrm{E}-02$ \\
\hline Pu-241 & $3.38 \mathrm{E}-03$ & $6.67 \mathrm{E}-05$ & $1.45 \mathrm{E}-08$ & & & $3.46 \mathrm{E}-02$ & $7.18 \mathrm{E}-04$ & $1.56 \mathrm{E}-07$ & & \\
\hline$P u-242$ & $6.73 \mathrm{E}-04$ & $1.33 E-05$ & $2.88 \mathrm{E}-09$ & & $1.14 \mathrm{E}-03$ & $6.41 \mathrm{E}-04$ & $1.33 E-05$ & $2.88 \mathrm{E}-09$ & & $1.14 \mathrm{E}-03$ \\
\hline Am-241 & 1.91E-02 & $3.76 \mathrm{E}-04$ & $8.16 E-08$ & & $3.24 E-02$ & $2.39 \mathrm{E}-02$ & $4.94 \mathrm{E}-04$ & 1.07E-07 & & $4.25 \mathrm{E}-02$ \\
\hline$A m-242 m$ & $7.71 \mathrm{E}-04$ & $1.52 \mathrm{E}-05$ & $3.30 \mathrm{E}-09$ & & $1.31 E-03$ & $7.39 \mathrm{E}-04$ & $1.53 \mathrm{E}-05$ & $3.32 \mathrm{E}-09$ & & $1.32 \mathrm{E}-03$ \\
\hline Am-243 & $1.57 \mathrm{E}-08$ & $3.09 \mathrm{E}-10$ & $6.71 \mathrm{E}-14$ & & $2.66 E-08$ & $1.82 \mathrm{E}-03$ & $3.76 \mathrm{E}-05$ & $8.16 \mathrm{E}-09$ & & $3.23 \mathrm{E}-03$ \\
\hline $\mathrm{Cm}-244$ & $5.13 E-03$ & 1.01E-04 & $2.20 \mathrm{E}-08$ & & & $1.63 \mathrm{E}-02$ & $3.37 E-04$ & $7.31 \mathrm{E}-08$ & & \\
\hline $\mathrm{Cm}-245$ & $6.76 \mathrm{E}-06$ & 1.33E-07 & $2.89 \mathrm{E}-11$ & & $1.15 E-05$ & $7.49 \mathrm{E}-06$ & $1.55 E-07$ & $3.36 \mathrm{E}-11$ & & 1.33E-05 \\
\hline $\mathrm{Cm}-246$ & $1.46 \mathrm{E}-12$ & $2.88 \mathrm{E}-14$ & & & & $2.48 \mathrm{E}-05$ & $5.15 \mathrm{E}-07$ & $1.12 \mathrm{E}-10$ & & \\
\hline $\mathrm{Cm}-247$ & $1.78 \mathrm{E}-18$ & $3.50 \mathrm{E}-20$ & $7.61 \mathrm{E}-24$ & & $3.02 \mathrm{E}-18$ & $1.21 \mathrm{E}-10$ & $2.51 E-12$ & $5.45 \mathrm{E}-16$ & & $2.16 \mathrm{E}-10$ \\
\hline Total & $1.00 E+02$ & $1.97 E+00$ & & $4.80 \mathrm{E}-03$ & $8.21 E-02$ & $1.00 E+02$ & $2.07 E+00$ & $4.04 \mathrm{E}-02$ & $4.84 E-03$ & $2.09 \mathrm{E}-01$ \\
\hline
\end{tabular}

WSRC-TR-94-00290 
WSRC-TR-2000-00290

Revision 4

Attachment 13

Waste Characterization Form for FHW-00001 


\section{EAV Low Level Waste Stream Characterization}

\begin{tabular}{|c|c|c|}
\hline $\begin{array}{l}\text { 1. Waste Stream ID } \\
\text { FHW00001 }\end{array}$ & $\begin{array}{l}\text { 2. Generating Facility } \\
\text { FTF, HTF }\end{array}$ & 3. Waste Organization \\
\hline \multicolumn{2}{|c|}{$\begin{array}{l}\text { 6. WITS Stream Description } \\
\text { Sludge contan'd waste from Tks } 9-15,21-23,30,32,35,36,40,42,43 \text {, and } 51\end{array}$} & $\begin{array}{l}\text { 7. Reason for Submittal } \\
\text { New Waste Stream }\end{array}$ \\
\hline \multicolumn{2}{|c|}{$\begin{array}{l}\text { 10. Activity Generating Waste } \\
\text { FTF and HTF Operations }\end{array}$} & $\begin{array}{l}\text { 11. Physical Form } \\
\text { Combustible }\end{array}$ \\
\hline
\end{tabular}

\begin{tabular}{|c|c|}
\hline 13. Valid Calculation Method for Waste & $\square$ Char by Pack \\
\hline$\square$ Dose-to-Curie $\quad \square \mathrm{sr}$ & $\triangle$ Curies or RAD Weight \\
\hline 17. Assigned Container Types & 18. DTC Containers \\
\hline$B-12(14)$ & All $\mathrm{B}-25 \mathrm{~s}$ \\
\hline B-25 (Yellow)-Light (6) & All $B-12 s$ \\
\hline B-25 (Yellow) 625\# (733) & All 55-gal Drums \\
\hline 55-gal Drum $(A, 7 A)(15)$ & Skid Pan \\
\hline Skid Pan (183) & \\
\hline
\end{tabular}

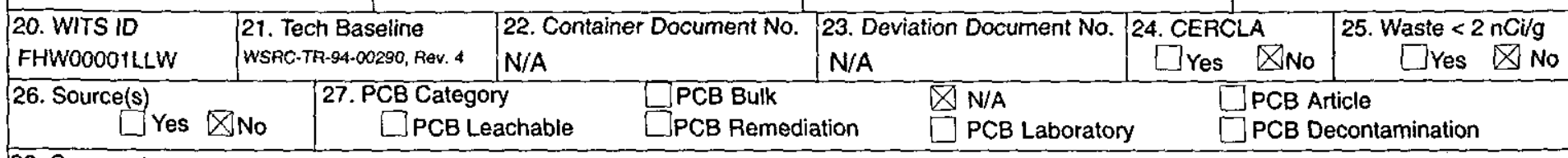

28. Comments

14. STC Constant 15. STC Min Valu N/A

\begin{tabular}{|c|c|c|}
\hline \multicolumn{2}{|l|}{ 19. Waste Description } & $\mathrm{Vol} \%$ \\
\hline Contaminated Equipment & 60 & \\
\hline Job Control Waste & 36 & \\
\hline Soil & 4 & \\
\hline & & \\
\hline $\begin{array}{l}\text { 23. Deviation Document No. } \\
\text { N/A }\end{array}$ & $\begin{array}{l}\text { 24. CERCLA } \\
{[] \text { Yes } \triangle \text { No }}\end{array}$ & $\begin{array}{r}\text { 25. Waste }<2 \mathrm{nCi} / \mathrm{g} \\
\square \text { Yes } \bigotimes \text { No }\end{array}$ \\
\hline $\begin{array}{l}\triangle \mathrm{N} / \mathrm{A} \\
\square \mathrm{PCB} \text { Laboraton }\end{array}$ & $\begin{array}{l}\square \mathrm{PCB} A \\
\square \mathrm{PCB} D\end{array}$ & ticle \\
\hline
\end{tabular}

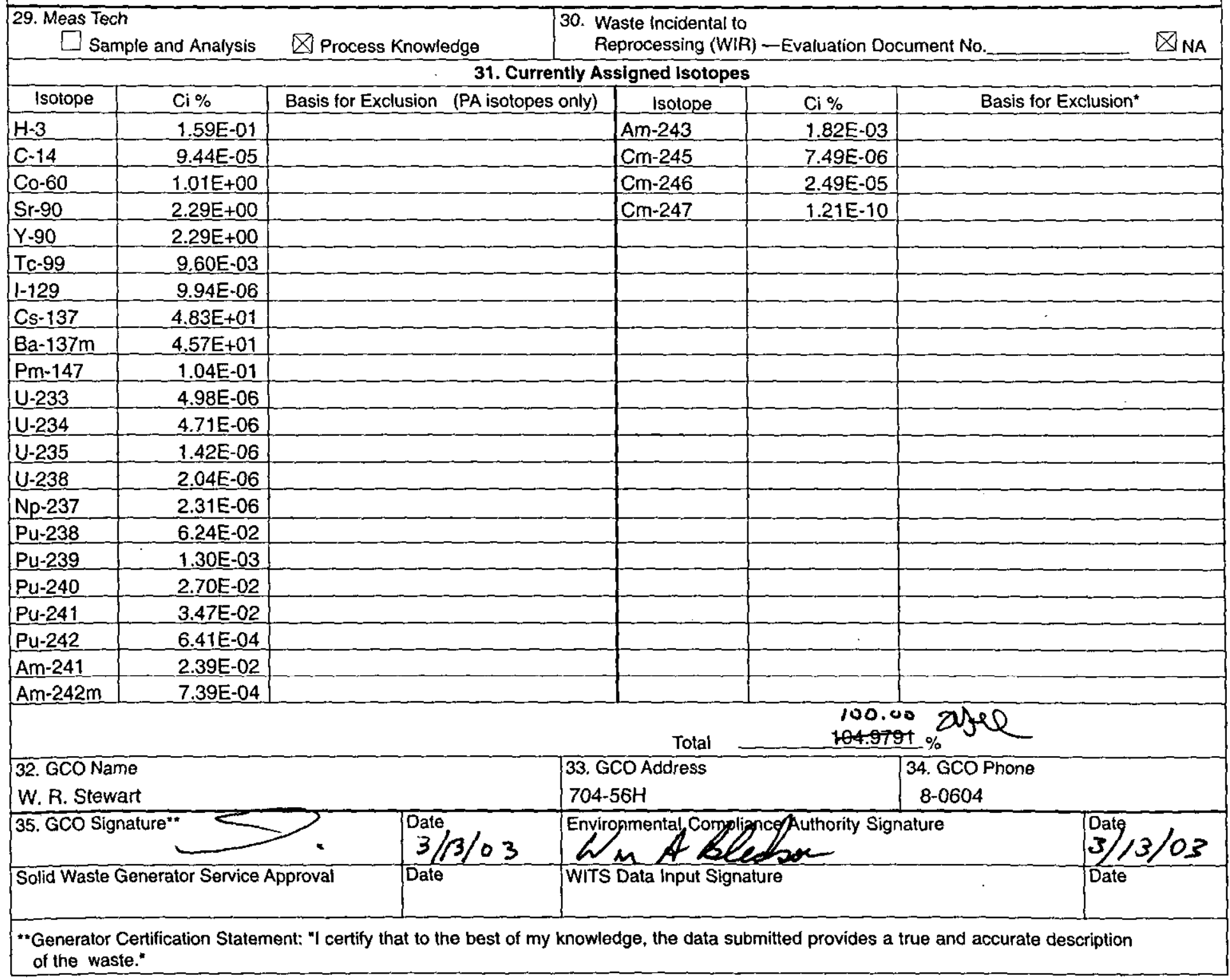

